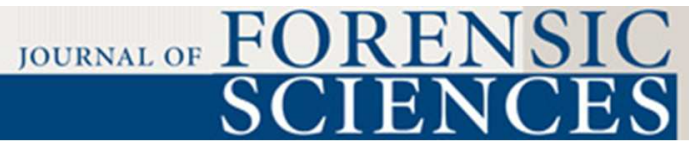

\title{
Soilwater conductivity analysis to date and locate clandestine graves of homicide victims
}

\begin{tabular}{|r|l|}
\hline Journal: & Journal of Forensic Sciences \\
\hline Manuscript ID: & JOFS-13-638.R1 \\
\hline Danuscript Type: & Technical Note \\
\hline Complete List of Authors: & $\begin{array}{l}\text { Pringle, Jamie; Keele University, School of Physical Sciences \& Geography } \\
\text { Cassella, John; Staffordshire University, Department of Forensic \& Crime } \\
\text { Science } \\
\text { Jervis, John; Keele University, School of Physical Sciences \& Geography } \\
\text { Williams, Anna; Huddersfield University, School of Applied Sciences; } \\
\text { Cranfield University, Cranfield Forensic Institute } \\
\text { Cross, Peter; University of Central Lancashire, School of Forensic and } \\
\text { Investigative Science; } \\
\text { Cassidy, Nigel; Keele University, School of Physical Sciences \& Geography }\end{array}$ \\
\hline Keywords: & $\begin{array}{l}\text { forensic science, forensic geophysics, conductivity, clandestine burials, } \\
\text { PMI, PBI }\end{array}$ \\
\hline \multicolumn{2}{|c}{} \\
\hline
\end{tabular}

SCHOLARONE ${ }^{\text {m }}$

Manuscripts 


\section{Soilwater Conductivity Analysis to Date and Locate Clandestine Graves of Homicide} Victims*

Jamie K. Pringle, ${ }^{1}$ Ph.D.; John P. Cassella, ${ }^{2}$ Ph.D.; John R. Jervis, ${ }^{1}$ Ph.D.; Anna

Williams, ${ }^{3,4}$ Ph.D; Peter Cross, ${ }^{5}$ M.Sc; and Nigel J Cassidy, Ph.D ${ }^{1}$

${ }^{1}$ School of Physical Sciences \& Geography, Keele University, Keele, Staffordshire, ST4 6DA, U.K.

${ }^{2}$ Department of Forensic \& Crime Science, Staffordshire University, Leek Road, Stoke-on-Trent, Staffordshire, ST4 2DF, U.K.

${ }^{3}$ Cranfield Forensic Institute, Cranfield University, Shrivenham, Berkshire, SN6 8LA, U.K.

${ }^{4}$ now at School of Applied Sciences, University of Huddersfield, Queensgate, Huddersfield, Yorkshire, HD1 3DH, U.K.

${ }^{5}$ School of Forensic \& Investigative Sciences, University of Central Lancashire, Preston, Lancashire, PR1 2HE, U.K.

*Initial results were orally presented at the Second International Conference of Engineering Geophysics of the European Association of Geoscientists and Engineers in Al Ain, United Arab Emirates, 24-27 November 2013.

Sources of funding:

John R. Jervis's PhD research was jointly funded by the U.K.'s Engineering and Physical Sciences Research Council (EPSRC) and RSK STATS Geoconsult Limited. A 2007 Keele Innovation in Teaching Award (No. 67) part-funded the generation of 
the Keele test site. A Cranfield Defence and Security Teaching Fellowship funded the generation of the Cranfield site.

\begin{abstract}
In homicide investigations, it is critically important that post-mortem (PMI) and postburial interval (PBI) of buried victims is determined accurately. However, clandestine graves can be difficult to locate; and the detection rates for a variety of search methods (ranging from simple ground probing through to remote imaging and nearsurface geophysics) can be very low. In this study, simulated graves of homicide victims were emplaced in three sites with contrasting soil types, bedrock and depositional environments. The long-term monthly in situ monitoring of grave soilwater revealed rapid increases in conductivity up to two years after burial, with the longest study evidencing declining values to background levels after 4.25 years. Results were corrected for site temperatures and rainfall to produce generic models of fluid conductivity as a function of time. The research suggest soilwater conductivity can give reliable PBI estimates for clandestine burials and therefore be used as a grave detection method.
\end{abstract}

Keywords: forensic science, forensic geophysics, conductivity, clandestine burials, PMI, 
Geoscientific methods are being increasingly utilised by forensic search teams for the detection and location of clandestine burials (1-2). Clandestine graves of murder victims are usually shallow, less than $3 \mathrm{~m}$ and typically $0.5 \mathrm{~m}$ below ground level or bgl $(3,4)$, but current detection rates are low and, without locating the victim's body, obtaining a successful conviction is more difficult $(5,6)$. Search investigators will typically use a variety of methods, which include scenario-based, feature focused, intelligence-led and systematic Standard Operating Procedures (SOPs) $(5,6)$. SOPs require investigators to follow sequential workflows, from reviewing case information, sourcing background / intelligence information and remote data analysis. This process occurs before determining search strategies, undergoing site reconnaissance and phased site investigations, and then intrusively investigating anomalous areas $(1,5,8)$. Geoscientific site investigation methods vary depending upon the specific case, search site and numerous other factors that are reviewed elsewhere (1), but can include scent-trained human remains detection dogs (7-8), forensic geomorphology (9-10), forensic botany (11-12) and entomology (13-14), near-surface geophysics (15-22), intrusive probing (10,23) and soil geoscience analysis (24-26).

After a body has been found, it is natural for investigators to focus on determining time since death. There has been extensive research on estimating the post-mortem interval (PMI) of very recently deceased individuals discovered above-ground that has been reviewed elsewhere (27), commonly using body cadaver temperatures (28-29), entomology (30) and entomofauna (31) and thanatochemistry (32). For longer deceased individuals, other common PMI dating methods include tissue decomposition (33), skeletal remains (34) and tooth odontology (35). 
Below-ground decomposition rates of discovered individuals has been shown to be highly variable (36), depending on organic content (37), various local environmental factors such as soil type (38-41) and organism accessibility (42), amongst other factors. These factors complicate the estimation of PMI for buried remains. Furthermore, it may useful to estimate the Post-Burial interval (PBI) as a guide to the PMI. However, the PMI and PBI may be different: a victim might not be buried immediately after death. In such cases, the PBI can be used as an estimate of the lower limit of the PMI.

The presence of a decomposing cadaver has also been shown to be detectable on the surrounding soil. For example, changes in soil chemistry $(24,25,37)$, such as changes in the levels of phosphates and nitrates (44), ninhydrin reactive nitrogen $(25,45)$, volatile organic compounds $(24,37,46)$ and $\mathrm{pH}(44,47)$ can all be detected. Changes in these soil properties can be used to estimate time since death. The decay of other items such as materials associated with a grave have also been suggested to allow a PBI to be estimated $(39,48)$.

Although relatively poorly understood, 'grave soil' has been shown to be detectable by near-surface geophysical search methods, specifically electrical resistivity $(21,18,49)$ and it's reciprocal, bulk ground conductivity (17). Geophysical research using simulated clandestine grave burials can provide critical information, for example, on optimal geophysical detection methods and equipment configurations $(15,50-52)$, as well as providing continuous datasets for comparison with real cases (50,53-55). Recent research has found that electrical resistivity anomalies over burials are predominantly due to conductive fluids in grave soil that vary temporally $(27,50,56)$ that may be due to decomposition (Fig. 1). It has been shown that it is 
possible to repeatedly extract in situ decomposition fluids from both a buried pig cadaver and background soilwater, without the need for repeated disturbance or numerous replicate samples as other authors have done. The resulting fluids can be simply analysed for conductivity using a hand-held meter, with initial results of a pilot two year monitoring study showing promise (27).

The aim of this was study was to expand the work of Pringle et al. (27). Firstly the aim was to obtain long-term (6 years) in situ grave soil water conductivity monitoring data for a U.K. simulated clandestine burial. Results were then used to generate linear regression curves to correlate measurements against PBI. Secondly the same experiment was conducted over a shorter time period at two other U.K. academic study sites to assess the method's robustness and variability in different soil and bedrock types. Thirdly, all results were corrected for local major climate variations (temperature and rainfall) to allow direct comparisons with other studies, and to allow search teams to utilise this method.. Fourthly, the potential for detecting clandestine burials using this method was assessed. 


\section{Methodology}

Study test sites

Three U.K. University test sites in different parts of the country were employed for this study, all in temperate climates that were typical of the U.K.

The University of Central Lancashire (UCLan) test site in Lancashire was situated in a dedicated research facility off campus in a rural environment on peat moorland (Fig. 2). The site lies $\sim 300 \mathrm{~m}$ above sea level. The local soil was determined onsite to be a dark brown, organic-rich hill peat with interbeds of silt and sand. Nearby records (57) indicated the Carboniferous (Westphalian) Pennine Lower Coal Measures Formation comprising a mixture of sandstone, mudstone and coal bedrock was present at least 4 $\mathrm{m}$ below ground level (bgl). This site has been used for several decomposition studies prior to this $(58,59)$, albeit spatially far enough away and downslope of the area to prevent any potential contamination issues; initial 'grave' soilwater conductivity values were also the same as for the control.

The Keele University test site in Staffordshire was situated in a restricted area in grassed semi-rural ground surrounded by deciduous woodland and hedges (Fig. 2). The site lies $\sim 200 \mathrm{~m}$ above sea level. The local soil was determined onsite to be a sandy loam with nearby borehole records (27) indicating the Carboniferous (Westphalian) Butterton Sandstone bedrock was present $\sim 2.5 \mathrm{~m}$ bgl. This site has also been previously used for a forensic geophysical study (27) but again these were situated far enough away and downslope to avoid any potential contamination issues; 
initial 'grave' soilwater conductivity values were also the same as for the control. The preliminary two years of results were published (27).

The Cranfield University test site in Wiltshire was situated in a restricted area on the Shrivenham campus in cleared semi-urban ground surrounded by deciduous woodland and hedges (Fig. 2). The site lies $\sim 80 \mathrm{~m}$ above sea level. The local soil was determined to be a mixed made-ground and sandy loam with nearby records (60) indicating Jurassic Oxford Clay Formation and Corallian Limestone bedrock both present at shallow depths bgl. The site had not been used for previous decomposition studies.

\section{Simulated graves}

For consistency, the simulated graves at all three sites (Fig. 2) were created following the same method, albeit at different dates (08/12/2007 for Keele University, 12/10/2010 for UCLan and 18/08/2011 for Cranfield Universities respectively). Each $\sim 2 \mathrm{~m} \mathrm{x} \sim 0.5 \mathrm{~m}$ grave was hand-excavated to $0.5 \mathrm{~m}$ below ground level (bgl), the respective ( $\sim 80 \mathrm{~kg}$ ) pig (Sus scrofa) cadavers, sourced from local abattoirs and dead for less than $12 \mathrm{~h}$ at the time of burial, were then placed within the graves. Simulated grave depths were based on published data on average depths of discovered human clandestine burials (87 in the U.S. (4) and 29 in the U.K. (3) respectively). The use of pig cadavers as human analogues is well established in forensic science studies as they have similar chemical compositions, body sizes, tissue:body fat ratios, and skin/ hair type to humans $(50,41,61)$. The use of pig cadavers at these sites had been approved by DEFRA and the respective University Ethics Committees. 
A soilwater sample lysimeter was placed within each grave between the pig cadaver and the grave wall (Fig. 3). The porous end cap of each model 1900 (SoilMoisture Equipment Corporation ${ }^{\mathrm{TM}}$ ) soilwater lysimeter was vertically inserted into a mixture of water and excavated soil which ensured good hydraulic conductivity between the grave and the lysimeter following standard practice (62). The simulated graves were then back-filled using the excavated soil and the overlying grass sods were then replaced. Control site lysimeters were installed $\sim 10 \mathrm{~m}$ away from each grave by digging narrow holes $(\sim 0.3 \mathrm{~m} \mathrm{x} \sim 0.3 \mathrm{~m})$ to $\sim 0.5 \mathrm{~m} \mathrm{bgl}$ and following the sample lysimeter emplacement procedure described above. These control lysimeters were placed far enough away and up-slope of the simulated graves to avoid any potential contamination with grave fluid (Fig. 2). Once installed, the exposed top of each lysimeter was sealed with a rubber stopper (Fig. 3) and a vacuum pump was employed to generate the established lysimeter suction of $65 \mathrm{KPa} 13$, in order for the instrument to draw fluid from the surrounding soil.

Sample collection and measurements

Two days before a sample was extracted, rubber stoppers from the respective lysimeters were removed and any fluid present extracted using a plastic syringe with a narrow tube attachment. This was to ensure that the analysed fluid had an accurate post-burial date when measured. The lysimeters were then resealed and repressurised as previously described. On the day of sampling (usually monthly, see Tables 1-3), the extraction procedure was repeated but any fluid was placed in a labelled plastic sample bottle; a portable WTW Instrument multi-line P4 temperaturecalibrated conductivity meter (6) was then immediately placed in the bottle and three 
conductivity values obtained; an average was therefore derived (Fig. 3). If no sample was present, this was recorded.

\section{Climatological data}

The closest weather stations run by the U.K. Meteorological Office were used to obtain average daily rainfall and air temperature readings over the respective monitoring periods (Tables 1-3). These were situated $\sim 2.4 \mathrm{~km}$ (Bacup), $\sim 0.2 \mathrm{~km}$ (Keele), and $\sim 3 \mathrm{~km}$ (Sevenhampton) away from the UCLan, Keele and Cranfield University study sites respectively. Keele University operates the Keele meteorological weather station which is close to the study site and recorded temperate weather patterns (Fig. 4). It recorded monthly minimum, maximum and average total rainfall of $2.6 \mathrm{~mm}, 167 \mathrm{~mm}$ and $64 \mathrm{~mm}$ respectively over the 2,004 day study period. The corresponding values recorded for UCLan were $23 \mathrm{~mm}, 278 \mathrm{~mm}$ and $126 \mathrm{~mm}$ respectively over the 610 day study period. Cranfield recorded $17 \mathrm{~mm}, 138 \mathrm{~mm}$ and $68 \mathrm{~mm}$ respectively over the 475 day study period.

The daily average temperatures from each site were used to convert post-burial days to Accumulated Degree Days (ADDs) (see 37). ADDs correct for local site temperature variations by weighting each day by the average daily temperature and then giving each burial day an ADD value. Therefore, for a 2-day period, in which the average temperature of the first day was $12^{\circ} \mathrm{C}$ and the second day was $15^{\circ} \mathrm{C}$, the ADD value for those 2 days would be 27 ADDs. Tables 1-3 summarises these datasets. 
Calculated monthly total rainfall (mm) data from all three sites were also used to obtain yearly monthly rainfall averages as well as obtaining yearly monthly rainfall averages for England over the study period from the U.K. Meteorological Office. Table 4 lists these datasets. The rainfall datasets were used to correct the measured soilwater measurements for local rainfall variation; conductivity values were multiplied by a rainfall correction factor, which was calculated by dividing the average monthly rainfall for England in a given year by the average monthly rainfall for the local area in the same year. Correction for rainfall was important as relatively high rainfall rates could potentially dilute grave soil water and hence reduce the measured conductivity values, and relatively low rainfall rates would effectively concentrate grave soil water and hence increase measured conductivity values. 


\title{
Results
}

\begin{abstract}
All measured climatological data from the three field sites showed cyclical seasonal variations in temperature as would be expected in a mid-latitude Northern hemisphere climate, with winter months being colder and wetter compared to warmer and dryer summer months (Fig, 4). However, there were significant variations between monitoring years; for example, the first three summers of the Keele study were warmer than subsequent summers, with rainfall in particular being variable between years (Fig. 4).
\end{abstract}

The field soilwater measurement results from the Keele test site (Fig. 5A) evidenced consistent background conductivity values over the 2,004 day study period (averaging $411 \pm 0.1 \mathrm{mS} / \mathrm{cm}$ ). The grave conductivity values (see Table 1 ) rapidly increased from $266 \pm 0.1 \mathrm{mS} / \mathrm{cm}$ (12 days) up to $28,800 \pm 0.1 \mathrm{mS} / \mathrm{cm}$ (307 days) before gradually increasing to a maximum of $33,400 \pm 0.1 \mathrm{mS} / \mathrm{cm}$ (671 days). Measured grave conductivity then rapidly decreased to $10,460 \pm 0.1 \mathrm{mS} / \mathrm{cm}$ (840 days) before gradually decreasing to typical background values of $499 \pm 0.1 \mathrm{mS} / \mathrm{cm}(1,621$ days $)$ until the end of the study period (2,004 days). These grave conductivity changes could be grouped into six linear regressions with good fits $\left(\mathrm{R}^{2}\right.$ values of $0.72-0.99$ see Fig. 5A).

The field soilwater measurement results from the UCLAN test site (Fig. 5A) evidenced consistent background conductivity values over the 511 day study period (averaging $331 \pm 0.1 \mathrm{mS} / \mathrm{cm}$ ). The grave conductivity values (see Table 2) rapidly increased from $570 \pm 0.1 \mathrm{mS} / \mathrm{cm}$ (12 days) up to $17,300 \pm 0.1 \mathrm{mS} / \mathrm{cm}$ (344 days), albeit being relatively constant at $\sim 5,000 \pm \mathrm{mS} / \mathrm{cm}$ between 181 to 287 days PBI. 
Measured grave conductivity then gradually decreased to $14,000 \pm 0.1 \mathrm{mS} / \mathrm{cm}$ at the end of the study period (511 days). Samples were not collected during a few months of the study period but this did not affect the overall trends.

The field soilwater measurement results from the Cranfield test site (Fig. 5A) evidenced consistent background conductivity values over the 264 day study period (averaging $829 \pm 0.1 \mathrm{mS} / \mathrm{cm}$ ). The grave conductivity values (see Table 3) rapidly increased from $674 \pm 0.1 \mathrm{mS} / \mathrm{cm}$ (22 days) up to $24,625 \pm 0.1 \mathrm{mS} / \mathrm{cm}$ (117 days), before rapidly decreasing to $10,987 \pm \mathrm{mS} / \mathrm{cm}$ at the end of the study period (264 days). Again, samples were not collected during some months of the study period but this did not affect the overall trends.

At each study site, there were local temperature variations, which directly affected decomposition rates (4), and these variations were removed from raw conductivity values by converting Post-Burial (day) Interval (PBI) to Accumulated Degree Days (ADD), as detailed in the methods. Local study site rainfall variations, which effect conductivity values as relative higher rainfall rates will reduce measured conductivities, were also removed by calculating each of the respective site's monthly average rainfall during the study and then correcting these by percentage changes against the average monthly rainfall for England (Table 4). The resulting climatecorrected Keele site data showed a much improved set of five linear correlations (Fig. 5B), with the other two study sites also showing similar conductivity results with the Keele study results over the same post-burial time periods (Fig. 5B). This method also accounted for the different respective study start dates (December 2007, October 2010 and August 2011 for the Keele, UCLAN and Cranfield studies respectively) and their associated seasonal local climate variations buried at different times of the year. 


\section{Discussion}

Every search for a murder victim in a clandestine burial is unique: the conditions (e.g. the local soil type, vegetation, climate and potential depositional environment) and factors relating to the burial (e.g. the victim's body size, burial depth bgl and season of deposition) will vary from case to case $(1,3,4,50)$. These factors will affect both successful detection of a clandestine burial and the determination of the PBI; the latter has, to-date, proved difficult to estimate when a grave is discovered $(37,63,64)$. Nevertheless, forensic search teams have an obligation "to use any means at their disposal to find [a body]" (5). When victims have been missing for a long period of time, it becomes even more of a challenge, as seen, for example, with the forensic high profile and ongoing U.K. search for Keith Bennett since his disappearance in 1964 (65).

These three studies have demonstrated that measuring 'grave' soilwater conductivity is a relatively robust geoscientific method for estimating a PBI of a discovered clandestine burial up to $\sim 1,600$ days / 13,500 ADDs after burial. The importance of correcting measured conductivity values for local rainfall and temperature information has also been shown by this study to be critical (Fig. 4). It is difficult with current methods to estimate a PBI after an individual is skeletonised $(1,3,27)$ and this proposed simple method may thus prove very beneficial to forensic recovery teams. Comparison of a pilot (66) and this study's preliminary (27) results has also noted that cadaver size did not have a significant effect on measured 'grave' soilwater conductivity measurements. 
The potential of this PBI estimation method was demonstrated with an early simulated clandestine burial study (27), where the measured conductivity value for a 'discovered' buried pig cadaver resulted in a $~ 10 \%$ date discrepancy between calculated and actual PBI over the 6 monthly monitoring period. It should be noted that a measured conductivity value could potentially give two PBI burial dates ( $c f$. Fig. 5); but this may still narrow down the PBI and may be more information than forensic investigators would otherwise have.

As the same experimental method was utilised at three U.K. study sites, with different local soil types, depositional environments and weather conditions over different temporal periods, and the geoscience dataset were still found to be reliable, the method findings give confidence that the methodology used is robust. Note however that there was some variability between comparable corrected results with the three study sites, which may be due to the differing depositional environments and soil types.

These studies have demonstrated that 'grave' soil water can clearly be differentiated from background soilwater by measuring soilwater conductivities and therefore this technique has the potential to also be a useful clandestine grave detection method. This dataset shows clear grave soil conductivity changes over time, with the most rapid changes occurring from burial up to $~ 300$ days / 3,000 ADDs after burial. This change is most likely due to decomposition changes (4,33) (Fig. 1). Forensic search teams could potentially detect clandestine graves by initially measuring conductivities in surface water downslope / downstream of identified potential burial site(s) as (5) and (2) have undertaken in their respective forensic searches. This would also require a programme of water sampling all around the identified potential burial site(s) in 
order to gain sufficient background conductivity readings to allow potential sites to be identified using this detection method. Whilst surface water sampling is relatively straightforward and commonly undertaken in environmental contamination surveys (1), forensic soilwater surveys would involve a significant amount of effort, from initial soil sampling of suspected burial sites and careful storage, to centrifuging to extract soilwater (25), and measuring their respective conductivity values to identify anomalous readings. This therefore would not be recommended as an initial search method; rather it should be undertaken when a search area has been narrowed down to an appropriate size. This does, however, have promise as other studies have shown decomposition fluids to be retained in the local soil environment and to be electrically detectable, even when physical remains have decayed (67).

Remaining unknown variables will be case-specific, but could include any delay between death and burial (e.g. storage), style of burial (50) and removal and reburial of the body or bodies (68). Other decomposing remains (e.g. animal cadavers) may also interfere with results. The proposed method could also be applied to determine the post-burial interval for other organic material, for example, illegal animal burials (69) or landfill leachate plumes (1).

\section{Conclusions and further work}

This long-term research project regularly extracted soilwater from three simulated clandestine burials in different soil and bedrock types and depositional environments in the UK. This has produced datasets of temporally varying conductivities over 6 years, evidencing relative rapid increasing of 'grave' soilwater conductivities up to 2 years post-burial, before declining to background conductivity values after 4.25 years 
of burial. Local climate variations of temperature and rainfall have been corrected for and comparable results have been obtained from the three sites using the same methodology which gives confidence in the method. Analysing soilwater conductivities of a discovered clandestine grave in situ would be relatively simple and could provide an estimate of the PBI for forensic search teams although this may be different to the PMI. Note that discovered burials plotted on the conductivity graphs may suggest two possible PBI values. The method could also potentially be used as a search tool if multiple soilwater and/or surface water samples are collected and analysed. This proposed method could also be applied to estimate the post-burial interval of other organic material, such as illegal animal burials or landfill plumes.

Further work should clearly first test this potential PBI method in a real forensic case of a discovered clandestine grave in order to determine its usefulness for forensic investigators. Secondly, it is important that the experiment is replicated in other soil types in order to quantitatively understand how this important variable affects the soilwater conductivity results. Thirdly, analytical chemical techniques should be utilised to examine the soilwater water samples. This would hopefully clarify the chemical changes that cause the variations in soilwater conductivity that were measured in this study. It may also determine whether individual elements, compounds or acids could be used as complimentary dating techniques. Fourthly, this experiment should be replicated using human cadavers as this may be a variable to consider. 


\section{Acknowledgements}

We acknowledge Tim Millington and Malcolm Wright for assistance in creating the study site and Ian Wilshaw for assistance in installing the lysimeters and providing local Keele weather data. The UK Metereological office is also thanked for providing weather data for the other test sites. The authors also wish to thank the numerous physical science under- and post-graduate students for undertaking pilot investigative projects. 


\title{
References:
}

1. Pringle JK, Ruffell A, Jervis JR, Donnelly L, Hansen J, Morgan R, et al. The use of geoscience methods for terrestrial forensic searches. Earth Sci Rev 2012;114:108-23.

2. Ruffell A, McKinley J. Geoforensics. Chichester: Wiley, 2008.

3. Hunter J, Cox M. Forensic archaeology: advances in theory and practice. Abingdon, VA: Routledge, 2005.

4. Manhein MH. Decomposition rates of deliberate burials: a case study of preservation. In: Haglund WD, Sorg MH, editors. Forensic taphonomy: the postmortem fate of human remains, Boca Raton: CRC, 1996;469-81.

5. Harrison M, Donnelly LJ. Locating concealed homicide victims: developing the role of geoforensics. In: Ritz K, Dawson L, Miller D, editors. Criminal and Environmental Soil Forensics, Dordrecht: Springer, 2009;197-219.

6. Larson DO, Vass AA, Wise M. Advanced scientific methods and procedures in the forensic investigation of clandestine graves. J Cont Crim Jus 2011;27:149-82.

\author{
7. Lasseter A, Jacobi KP, Farley R, Hensel L. Cadaver dog and handler team \\ capabilities in the recovery of buried human remains in the Southeastern United \\ States. J For Sci 2003;48:1-5.
}


8. Dupras TL, Schultz JJ, Wheeler SM, Williams LJ. Forensic recovery of human remains. Boca Raton: CRC Press, 2006.

9. Ruffell A, McKinley J. Forensic geomorphology. Geomorphology 2014;206:14-22.

10. Killam EW. The detection of human remains. Springfield: Charles C. Thomas, 2004.

11. Aquila I, Ausania F, Di Nunzio C, Serra A, Boca S, Capelli A, et al. The role of forensic botany in crime scene investigation: case report and review of literature. J For Sci 2014; DOI: 10.1111/1556-4029.12401

12. Coyle HM. Forensic botany: principles and applications to criminal casework. Boca Raton: CRC Press, 2005.

13. Gennard D. Forensic entomology: an introduction. $2^{\text {nd }}$ ed, Chichester: WileyBlackwell, 2012.

14. Amendt J, Campobasso CP, Gaudry E, Reiter C, LeBlanc HN, Hall MJR. Best practice in forensic entomology: standards and guidelines. Int J Legal Med 2007;121:90-104.

15. France DL, Griffin TJ. Swanburg JG, Lindemann JW, Davenport GC, Trammell V. et al. A multidisciplinary approach to the detection of clandestine graves. J For Sci 1992;37:1445-58. 
16. Powell K. Detecting human remains using near-surface geophysical instruments. Expl Geophys 2004;35:88-92.

17. Nobes DC. The search for "Yvonne": a case example of the delineation of a grave using near-surface geophysical methods. J For Sci 2000;45:715-21.

18. Pringle JK, Jervis JR. Electrical resistivity survey to search for a recent clandestine burial of a homicide victim, UK. For Sci Int 2010;202(1-3):e1-7.

19. Novo A, Lorenzo H, Ria F, Solla M. 3D GPR in forensics: finding a clandestine grave in a mountainous environment. For Sci Int 2011;204:134-8.

20. Schultz JJ. Using ground-penetrating radar to locate clandestine graves of homicide victims: forming forensic archaeology partnerships with law enforcement. Homicide Stud 2007;11:15-29.

21. Cheetham P. Forensic geophysical survey. In: Hunter J, Cox, M, editors. Forensic archaeology: advances in theory and practice. Abingdon: Routledge, 2005:62-95.

22. Witten A, Brooks R, Fenner T. The Tulsa Race Riot of 1921: a geophysical study to locate a mass grave. Leading Edge 2001;20:655-60.

23. Owsley DW. Techniques for locating burials, with emphasis on the probe. J For Sci 1995;40:735-40. 
24. Vass AA, Smith RR, Thompson CV, Burnett MN, Dulgerian N, Eckenrode BA. Odor analysis of decomposing human remains. J For Sci 2008;53:384-91.

25. Carter DO, Yellowlees D, Tibbett M. Using ninhydrin to detect gravesoil. J For Sci 2008;53:397-400.

26. Dekeirsschieter J, Verheggen FJ, Gohy M, Hubrecht F, Bourguignon, L, Lognay G, et al. Cadaveric volatile organic compounds released by decaying pig carcasses (Sus domesticus) in different biotopes. For Sci Int 189;2009:46-53.

27. Pringle JK, Cassella JP, Jervis JR. Preliminary soilwater conductivity analysis to date clandestine burials of homicide victims. For Sci Int 2010;198:126-33.

28. Marshall TK. Estimating the time of death: the use of the cooling formula in the study of post-mortem body cooling. J For Sci 1962;7:189-210.

29. Henssge C. Death time estimation in case work. The rectal temperature time of death nomogram. For Sci Int 1988;38:209-36.

30. Arnaldos M, Garcia I, Romera E, Presa JJ, Luna A, Estimation of post-mortem interval in real cases based on experimentally obtained entomological evidence, For Sci Int 2005;149:57-65.

31. Marchenko MI, Medicolegal relevance of cadaver entomofauna for the determination of the time of death, For Sci Int 2001;120:89-109. 
32.Madea B, Is there recent progress in the estimation of the post-mortem interval by means of thanatochemistry? For Sci Int 2005;151:139-49.

33. Janaway RC, Percival SL, Wilson A. Decomposition of human remains. In: Percival SL, editor. Microbiology and Aging: Clinical Manifestations: New York: Springer, 2009:13-334.

34. Ramsthaler F, Kreutz K, Zipp K, Verhoff MA. Dating skeletal remains with luminol-chemiluminescence: validity, intra- and inter-observer error, For Sci Int 2009; 187:47-50.

35. McKeown AH, Bennett JL. A preliminary investigation of postmortem tooth loss, J For Sci 1995;40:755-57.

36. Rodriguez WC. Decomposition of buried and submerged bodies, In: Haglund WD, Sorg MH editors. Forensic Taphonomy: The Postmortem Fate of Human Remains. Boca Raton: CRC Press, 1997:459-68.

37. Vass AA, Bass WM, Wolt JD, Foss JE, Ammons JT. Time since death determinations of human cadavers using soil solution. J For Sci 1992;37:1236-53.

38. Forbes SL, Dent BB, Stuart BH, The effect of the burial environment on adipocere formation. For Sci Int. 2005;154:24-34. 
39. Wilson AS, Janaway RC, Holland AD, Dodson HI, Barran E, et al. Modelling the buried human body environment in upland climes using three contrasting field sites. For Sci Int 2007;169:6-18.

40. Turner B, Wiltshire P. Experimental validation of forensic evidence: a study of the decomposition of buried pigs in heavy clay soil. For Sci Int 1999;101:113-22.

41. Carter DO, Tibbett M. Cadaver decomposition and soil: processes. In: Tibbett M, Carter DO, editors. Soil Analysis in Forensic Taphonomy: Chemical and Biological Effects of Buried Human Remains. Boca Raton: CRC Press, 2009;29-52.

42. Hopkins DW, The role of soil organisms in terrestrial decomposition, In: Tibbett M, Carter DO, editors. Soil Analysis in Forensic Taphonomy: Chemical and Biological Effects of Buried Human Remains. Boca Raton: CRC Press, 2009;53-66.

43. Davla M, Kalácska M, Moore TR, Costopopoulos A. Detecting graves with methane. Geoderma 2012;189-190:18-27.

44. Matias MJ, Marques da Silva M, Goncalves L, Peralta C, Grangeia C, et al. An investigation into the use of geophysical methods in the study of aquifer contamination by graveyards. Near Surf Geophys;2:131-6.

45. Van Belle LE, Carter DO, Forbes SL. Measurement of ninhydrin reactive nitrogen influx into gravesoil during aboveground and belowground carcass (Sus domesticus) decomposition. For Sci Int 2009;193:37-41. 
46. Dekeirsschieter J, Verheggen FJ, Gohy M, Hubrecht F, Bourguignon L, et al.

Cadaveric volative organic compounds released by decaying pig carcasses (Sus

domesticus) in different biotopes. For Sci Int 2009;189:46-53.

47. Benninger LA, Carter DO, Forbes SL. The biochemical alteration of soil beneath a decomposing carcass. For Sci Int 2008;180:70-5.

48. Janaway RC. Decomposition of materials associated with buried cadavers. In:

Tibbett M, Carter DO, editors. Soil Analysis in Forensic Taphonomy: Chemical and

Biological Effects of Buried Human Remains. Boca Raton: CRC Press, 2009;153-

201.

49. Hansen JD, Pringle JK, Goodwin J. GPR and bulk ground resistivity surveys in graveyards: locating unmarked burials in contrasting soil types. For Sci Int 2014;237:e14-29.

50. Pringle JK, Jervis JR, Hansen JD, Cassidy NJ, Jones GM, Cassella JP. Geophysical monitoring of simulated clandestine graves using electrical and ground penetrating radar methods: 0-3 years. J For Sci 2012;57:1467-86.

51. Schultz JJ, Martin MM. Controlled GPR grave research: comparisons of reflection profiles between 500 and $250 \mathrm{MHz}$ antennae. For Sci Int 2011;209:64-9.

52. Pringle JK, Jervis J, Cassella JP, Cassidy NJ, Time-lapse geophysical investigations over a simulated urban clandestine grave. J For Sci 2008;53:1405-17. 
53. Schultz JJ, Martin MM. Monitoring controlled graves representing common burial scenarios with ground penetrating radar. J App Geophys 2012;83:74-89.

54. Schultz JJ. Sequential monitoring of burials containing small pig cadavers using ground-penetrating radar. J For Sci 2008;53:279-87.

55. Schultz JJ, Collins ME, Falsetti AB. Sequential monitoring of burials containing large pig cadavers using ground-penetrating radar. J For Sci 2006;51:607-16.

56. Jervis JR, Pringle JK, Tuckwell GW. Time-lapse resistivity surveys over simulated clandestine graves. For Sci Int 2009a;192:7-13.

57. E. Hough, Geology of the Burnley area (SD82NW and SD83SW), British Geological Survey Internal Report WA/00/30 (2004). Available online at: http://nora.nerc.ac.uk/20026/1/WA_00030_Burnley.pdf Last accessed 21st June 2013.

58. Simmons T, Cross PA, Adlam RE, Moffat, C. The influence of insects on decomposition rate in buried and surface remains. J For Sci 2010;44:889-92.

59. Gruenthal A, Moffatt C, Simmons T. Differential decomposition patterns in charred versus un-charred remains. J For Sci 2012;57:13-18.

60. Birbeck, V. Excavations at Watchfield, Shrivenham, Oxfordshire. Wessex Archaeology, 1998. 
61. Stokes KL, Forbes SL, Tibbett M. Human versus animal: contrasting decomposition dynamics of mammalian analogues in experimental taphonomy. J For Sci 2013;58:583-91.

62. Grossman J, Udluft P. The extraction of soil water by the suction-cup method: a review. J Soil Sci 1991;42:83-93.

63. Carter DO, Yellowlees D, Tibbett M. Temperature affects microbial decomposition of cadavers (Rattus rattus) in contrasting soils. Appl Soil Ecol 2008;40:129-37.

64. Breitmeier D, Graefe-Kirci U, Albrecht K, Weber N, Tröger HD, Kleeman WJ. Evaluation of the correlation between time corpses spent in in-ground graves and findings at exhumation. For Sci Int 2005;154:218-23.

65. Fenning PJ, Donnelly LJ. Geophysical techniques for forensic investigation. Geol Soc London Spec Pub 2004;232:11-20.

66. Jervis JR, Pringle JK, Cassella JP, Tuckwell GT. Using soil and groundwater to understand resistivity surveys over a simulated clandestine grave. In: Ritz K, Dawson L, Miller D, editors. Criminal and environmental soil forensics. Dordrecht, The Netherlands: Springer, 2009;271-84.

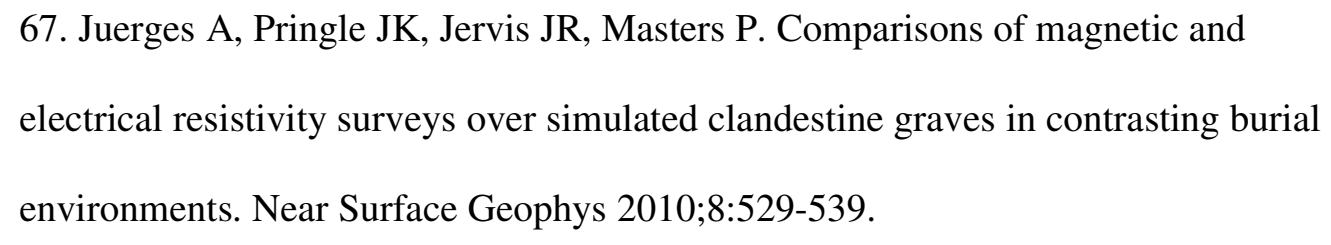


1

2

3

4

5

6

7

8

10

11

12

13

14

15

16

17

18

19

20

21

22

23

24

25

26

27

28

29

30

31

32

33

34

35

36

37

38

39

40

41

42

43

44

45

46

47

48

49

50

51

52

53

54

55

56

57

58

59

60

68. Brown AG. The use of forensic botany and geology in war crimes investigations in NE Bosnia. For Sci Int 2006;163:204-10.

69. Ruffell A, Kulessa B. Application of geophysical techniques in identifying illegally buried toxic waste. Env For 2009;10:196-207. 
Additional information and reprint requests:

Jamie K. Pringle, Ph.D.

School of Physical Sciences \& Geography

William Smith Building

Keele University

Keele

Staffordshire ST5 5BG

U.K.

E-mail: j.k.pringle@keele.ac.uk 


\section{FIGURE CAPTIONS:}

FIG. 1. Four main clandestine burial decompositional stages. (A) Recent burial, surface expression is most obvious. (B) Early decomposition with search dogs and/or methane probes being optimal. (C) Late-stage decomposition with grave soil fluids. (D) Final skeletonised decomposition. Modified from (1).

FIG. 2. Annotated photographs of the three test sites $(\mathrm{U}=\mathrm{UCLan}, \mathrm{K}=$ Keele and $\mathrm{C}=$ Cranfield Universities) with respective locations on U.K. map (inset). Respective simulated clandestine grave and control lysimeter positions also shown.

FIG. 3. Simulated clandestine burial annotated photographs from Keele study site of (A) simulated grave contents and (B) fluid measuring accessories (see text). Modified from (27).

FIG. 4. Graphical climate summary of rainfall (bars) and temperature (line) data from Keele University weather station, from our data and previously published data $(27,50)$.

FIG. 5. Measured fluid conductivity results showing (A) Keele test site and (B) corrected for both temperature and monthly average rainfall (see text). Comparison data from Cranfield (crosses) and UCLan (squares) study sites also shown. 
TABLES

\begin{tabular}{|c|c|c|c|c|c|}
\hline $\begin{array}{c}\text { Sample } \\
\text { date }\end{array}$ & $\begin{array}{c}\text { Post- } \\
\text { burial } \\
\text { days / } \\
\text { interval } \\
\text { (PBI) }\end{array}$ & $\begin{array}{l}\text { Accum- } \\
\text { ulated } \\
\text { Degree } \\
\text { Days } \\
\text { (ADD) }\end{array}$ & $\begin{array}{c}\text { Field- } \\
\text { measured } \\
\text { 'grave' } \\
\text { conductivity } \\
(\mathrm{mS} / \mathrm{cm})\end{array}$ & $\begin{array}{c}\text { Rainfall } \\
\text { england- } \\
\text { corrected } \\
\text { grave } \\
\text { conductivity }\end{array}$ & $\begin{array}{c}\text { Field- } \\
\text { measured } \\
\text { 'control' } \\
\text { conductivity } \\
(\mathrm{mS} / \mathrm{cm})\end{array}$ \\
\hline 08/12/2007 & 0 & 0 & & & \\
\hline $19 / 12 / 2007$ & 12 & 27 & 729 & 743 & 463 \\
\hline $10 / 01 / 2008$ & 34 & 114 & 1597 & 1463 & 422 \\
\hline $17 / 01 / 2008$ & 41 & 149 & 1780 & 1631 & 414 \\
\hline $31 / 01 / 2008$ & 55 & 244 & 2060 & 1888 & 517 \\
\hline $14 / 02 / 2008$ & 69 & 308 & 2680 & 2456 & 527 \\
\hline 28/02/2008 & 84 & 364 & 2740 & 2511 & no sample \\
\hline $13 / 03 / 2008$ & 97 & 436 & 3520 & 3226 & 560 \\
\hline 27/03/2008 & 111 & 498 & 4390 & 4023 & 587 \\
\hline $10 / 04 / 2008$ & 125 & 588 & 5400 & 4949 & 626 \\
\hline 24/04/2008 & 139 & 683 & 5860 & 5370 & 625 \\
\hline 08/05/2008 & 153 & 850 & 6610 & 6057 & 617 \\
\hline $22 / 05 / 2008$ & 167 & 1035 & 9130 & 8367 & 442 \\
\hline 05/06/2008 & 181 & 1225 & 11610 & 10639 & 423 \\
\hline 19/06/2008 & 195 & 1416 & 13810 & 12656 & 350 \\
\hline 17/07/2008 & 223 & 1815 & 18640 & 17082 & 415 \\
\hline $14 / 08 / 2008$ & 251 & 2266 & 22100 & 20253 & 430 \\
\hline $11 / 09 / 2008$ & 279 & 2673 & no sample & no sample & 439 \\
\hline 09/10/2008 & 307 & 2992 & 28800 & 26392 & 419 \\
\hline 06/11/2008 & 335 & 3225 & 30000 & 27492 & 401 \\
\hline 04/12/2008 & 363 & 3368 & 29600 & 27126 & no sample \\
\hline 29/01/2009 & 419 & 3497 & 30800 & 27456 & no sample \\
\hline 26/02/2009 & 447 & 3566 & 29800 & 26565 & 428 \\
\hline 26/03/2009 & 475 & 3740 & 29700 & 26475 & 452 \\
\hline 23/04/2009 & 503 & 3987 & 30200 & 26921 & 479 \\
\hline $21 / 05 / 2009$ & 531 & 4274 & 31500 & 28080 & 495 \\
\hline $18 / 06 / 2009$ & 559 & 4659 & 30900 & 27545 & 424 \\
\hline 05/09/2009 & 638 & 5883 & 31400 & 27991 & 413 \\
\hline 08/10/2009 & 671 & 6306 & 33400 & 29774 & no sample \\
\hline 03/12/2009 & 727 & 6777 & 24600 & 21929 & 354 \\
\hline $30 / 12 / 2009$ & 754 & 6827 & 22500 & 20057 & 346 \\
\hline 28/01/2010 & 783 & 6837 & 18940 & 17033 & 364 \\
\hline $26 / 02 / 2010$ & 812 & 6868 & 13030 & 11718 & 375 \\
\hline 26/03/2010 & 840 & 7000 & 10460 & 9407 & 386 \\
\hline 27/04/2010 & 872 & 7251 & 10480 & 9425 & 396 \\
\hline 27/05/2010 & 902 & 7582 & 9400 & 8454 & 369 \\
\hline 25/06/2010 & 931 & 7985 & 9350 & 8409 & 335 \\
\hline
\end{tabular}




$\begin{array}{lccccc}30 / 07 / 2010 & 966 & 8552 & 10200 & 9173 & \text { no sample } \\ 01 / 10 / 2010 & 1029 & 9421 & \text { no sample } & \text { no sample } & 376 \\ 29 / 10 / 2010 & 1057 & 9678 & 6210 & 5585 & 367 \\ 10 / 12 / 2010 & 1099 & 9794 & 6670 & 5999 & 357 \\ 04 / 01 / 2011 & 1124 & 9786 & 5610 & 4569 & \text { no sample } \\ 11 / 02 / 2011 & 1162 & 9940 & 3540 & 2883 & 335 \\ 11 / 03 / 2011 & 1190 & 10053 & 2370 & 1930 & 342 \\ 18 / 04 / 2011 & 1228 & 10391 & 2300 & 1873 & 350 \\ 23 / 05 / 2011 & 1263 & 10818 & 3110 & 2533 & 326 \\ 22 / 06 / 2011 & 1293 & 11202 & \text { no sample } & \text { no sample } & 304 \\ 03 / 01 / 2012 & 1487 & 13439 & 1375 & 1178 & \text { no sample } \\ 20 / 02 / 2012 & 1536 & 13584 & 855 & 733 & 330 \\ 12 / 03 / 2012 & 1557 & 13727 & 646 & 553 & 357 \\ 16 / 04 / 2012 & 1592 & 13985 & 716 & 613 & \text { no sample } \\ 15 / 05 / 2012 & 1621 & 14214 & 499 & 428 & 394 \\ 03 / 07 / 2012 & 1670 & 14872 & 415 & 356 & 395 \\ 03 / 08 / 2012 & 1701 & 15331 & 369 & 316 & 385 \\ 05 / 09 / 2012 & 1734 & 15853 & \text { no sample } & \text { no sample } & 394 \\ 04 / 10 / 2012 & 1763 & 16198 & 392 & 336 & 391 \\ 09 / 11 / 2012 & 1799 & 16454 & 413 & 354 & 402 \\ 07 / 12 / 2012 & 1827 & 16584 & 363 & 311 & 410 \\ 07 / 01 / 2013 & 1858 & 16722 & 335 & 260 & 372 \\ 18 / 02 / 2013 & 1900 & 16781 & 344 & 267 & 323 \\ 13 / 03 / 2013 & 1923 & 16823 & 350 & 272 & 278 \\ 18 / 04 / 2013 & 1959 & 16954 & 394 & 306 & \text { no sample } \\ 04 / 06 / 2013 & 2006 & 17423 & 402 & 313 & 300 \\ 30 / 11 / 2013 & 2185 & 19702 & 415 & 323 & 396\end{array}$

TABLE 1. Summary of measured conductivity values and local temperature data from Keele study site over the monitoring period. Conductivity and temperature data are from our new data and previously published data $(27,50)$. No sample $=$ no fluid was able to be extracted. Stated measurements are averages with a $\pm 0.1 \mathrm{mS} / \mathrm{cm}$ accuracy. 
Date

\begin{tabular}{|c|c|c|}
\hline $\begin{array}{l}\text { Post- } \\
\text { burial } \\
\text { days / }\end{array}$ & $\begin{array}{c}\text { Accum- } \\
\text { ulated } \\
\text { Degree }\end{array}$ & $\begin{array}{c}\text { Field- } \\
\text { measured } \\
\text { 'grave' }\end{array}$ \\
\hline $\begin{array}{c}\text { interval } \\
\text { (PBI) }\end{array}$ & $\begin{array}{l}\text { Days } \\
\text { (ADD) }\end{array}$ & $\begin{array}{c}\text { conductivity } \\
(\mathrm{mS} / \mathrm{cm})\end{array}$ \\
\hline
\end{tabular}

Rainfall
england-
corrected
grave
conductivity

0

$12 / 10 / 2010$
$28 / 10 / 2010$

0

$04 / 11 / 2010 \quad 23$

$11 / 11 / 2010$

$04 / 02 / 2011$

$04 / 03 / 2011$

$11 / 04 / 2011$

$11 / 05 / 2011$

$14 / 06 / 2011$

$07 / 07 / 2011$

$26 / 07 / 2011$

21/09/2011

27/10/201

$12 / 01 / 2012$

$06 / 03 / 2012$
0

$16 \quad 132$

30

115

143

181

211

245

268

287

344

380

457

511

$23 \quad 206$

248

421

572

866

1220

1605

1936

2204

3008

3449

4007

4217

570
780
500
2300
3500
6900
4500
4600
5200
6450
17300
16500
13220
14000

1096

$1096 \quad 250$

$1500 \quad 230$

$961 \quad 190$

$4877 \quad 100$

$7421 \quad 100$

$14630 \quad 460$

$9541 \quad 400$

$9753 \quad 370$

$11026 \quad 310$

$13676 \quad 250$

$36682 \quad 850$

no sample $\quad 270$

$22540 \quad 200$

$23870 \quad 650$

TABLE 2. Summary of measured conductivity values and local temperature data from the UCLan study site over the monitoring period. Stated measurements are averages with a $\pm 0.1 \mathrm{mS} / \mathrm{cm}$ accuracy. 


$\begin{array}{lccccc}\text { Date } & \begin{array}{c}\text { Post- } \\ \text { burial } \\ \text { days / } \\ \text { interval } \\ \text { (PBI) }\end{array} & \begin{array}{c}\text { Accum- } \\ \text { ulated } \\ \text { Degree } \\ \text { Days } \\ \text { (ADD) }\end{array} & \begin{array}{c}\text { Field- } \\ \text { measured } \\ \text { 'grave' } \\ \text { conductivity } \\ \text { (mS/cm) }\end{array} & \begin{array}{c}\text { Rainfall } \\ \text { england- } \\ \text { corrected } \\ \text { grave } \\ \text { conductivity }\end{array} & \begin{array}{c}\text { Field- } \\ \text { measured } \\ \text { 'control' } \\ \text { conductivity } \\ \text { (mS/cm) }\end{array} \\ \text { 18/08/11 } & 0 & 0 & - & - & - \\ 09 / 09 / 11 & 22 & 347 & 1918 & 1646 & 674 \\ 15 / 09 / 11 & 28 & 434 & 4945 & 4244 & 330 \\ 19 / 09 / 11 & 32 & 488 & 5475 & 4699 & 890 \\ 26 / 09 / 11 & 39 & 589 & 4638 & 3980 & 1138 \\ 29 / 09 / 11 & 42 & 642 & 4103 & 3521 & 800 \\ 05 / 10 / 11 & 48 & 749 & 8113 & 6963 & 633 \\ 12 / 10 / 11 & 55 & 849 & 7600 & 6523 & 1094 \\ 21 / 10 / 11 & 64 & 934 & 8230 & 7063 & 1173 \\ 28 / 10 / 11 & 71 & 1011 & 9660 & 8290 & 1187 \\ 13 / 12 / 11 & 117 & 1412 & 24625 & 21134 & 595 \\ 22 / 02 / 12 & 188 & 1763 & 21805 & 18589 & 611 \\ 24 / 04 / 12 & 250 & 2261 & 9223 & 7863 & 725 \\ 04 / 05 / 12 & 260 & 2343 & 9647 & 8224 & 510 \\ 08 / 05 / 12 & 264 & 2379 & 10987 & 9366 & 591\end{array}$

TABLE 3. Summary of measured conductivity values and local temperature data from the Cranfield study sites over the monitoring period. Stated measurements are averages with a $\pm 0.1 \mathrm{mS} / \mathrm{cm}$ accuracy. 


$\begin{array}{ccccc}\text { Year } & \text { England } & \text { Keele } & \text { UCLAN } & \text { Cranfield } \\ 2007 & 77.9 & 79.4 & - & - \\ 2008 & 81.8 & 75 & - & - \\ 2009 & 72.9 & 65 & - & - \\ 2010 & 60.6 & 54.5 & 116.5 & - \\ 2011 & 59.4 & 48.4 & 126 & 51 \\ 2012 & 93.8 & 80.4 & 160 & 80 \\ 2013 & 81.3 & 63.2 & - & - \\ \text { average } & \mathbf{7 5 . 4} & \mathbf{6 6 . 6} & \mathbf{1 3 4 . 2} & \mathbf{6 6}\end{array}$

TABLE 4. Summary of monthly average rainfall data from the respective study sites over the monitoring period. Measurements have $1 \mathrm{~mm}$ accuracy. 
FIG. 1. Four main clandestine burial decompositional stages. (A) Recent burial, surface expression is most obvious. (B) Early decomposition with search dogs and/or methane probes being optimal. (C) Late-stage decomposition with grave soil fluids. (D) Final skeletonised decomposition. Modified from (1).
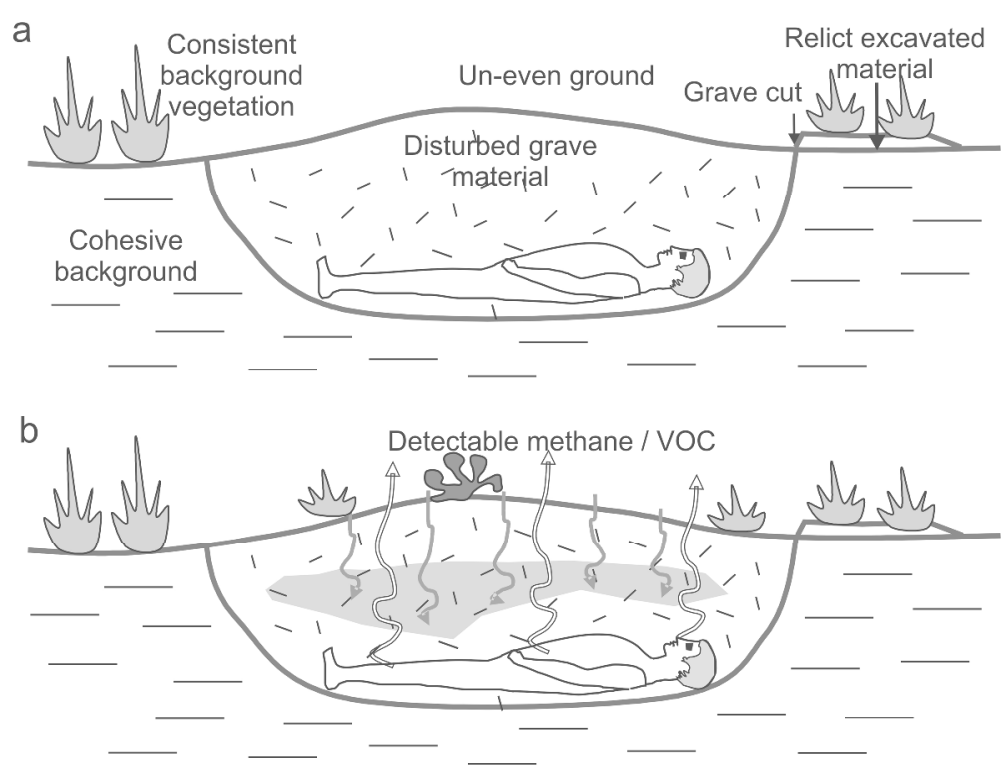

C

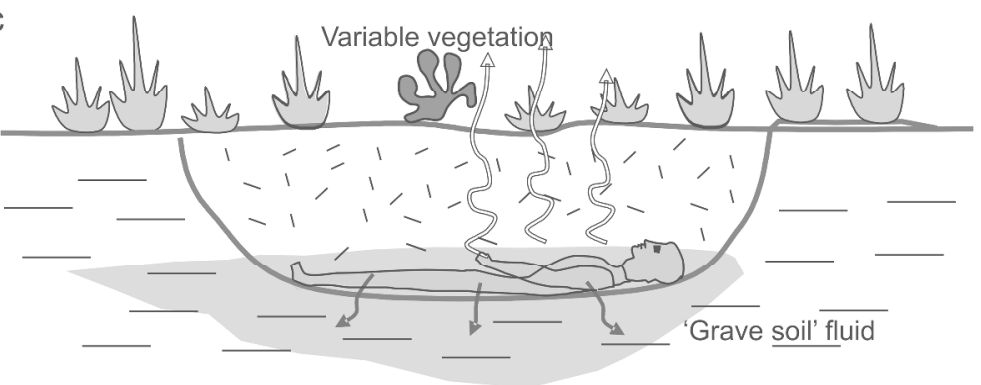

d

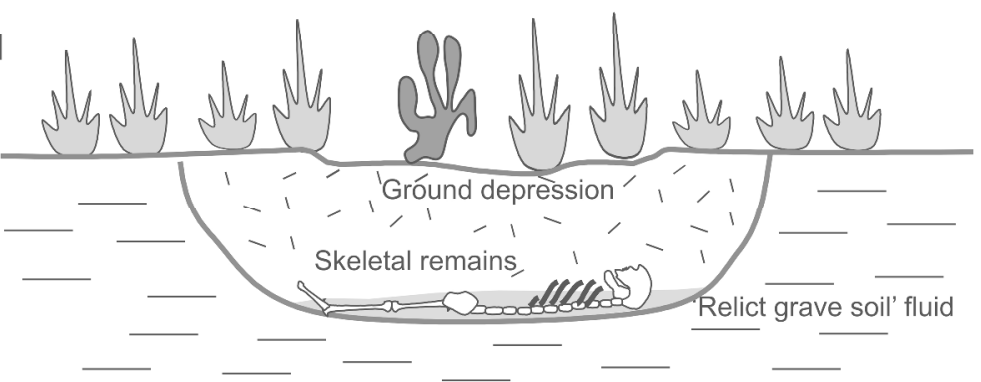



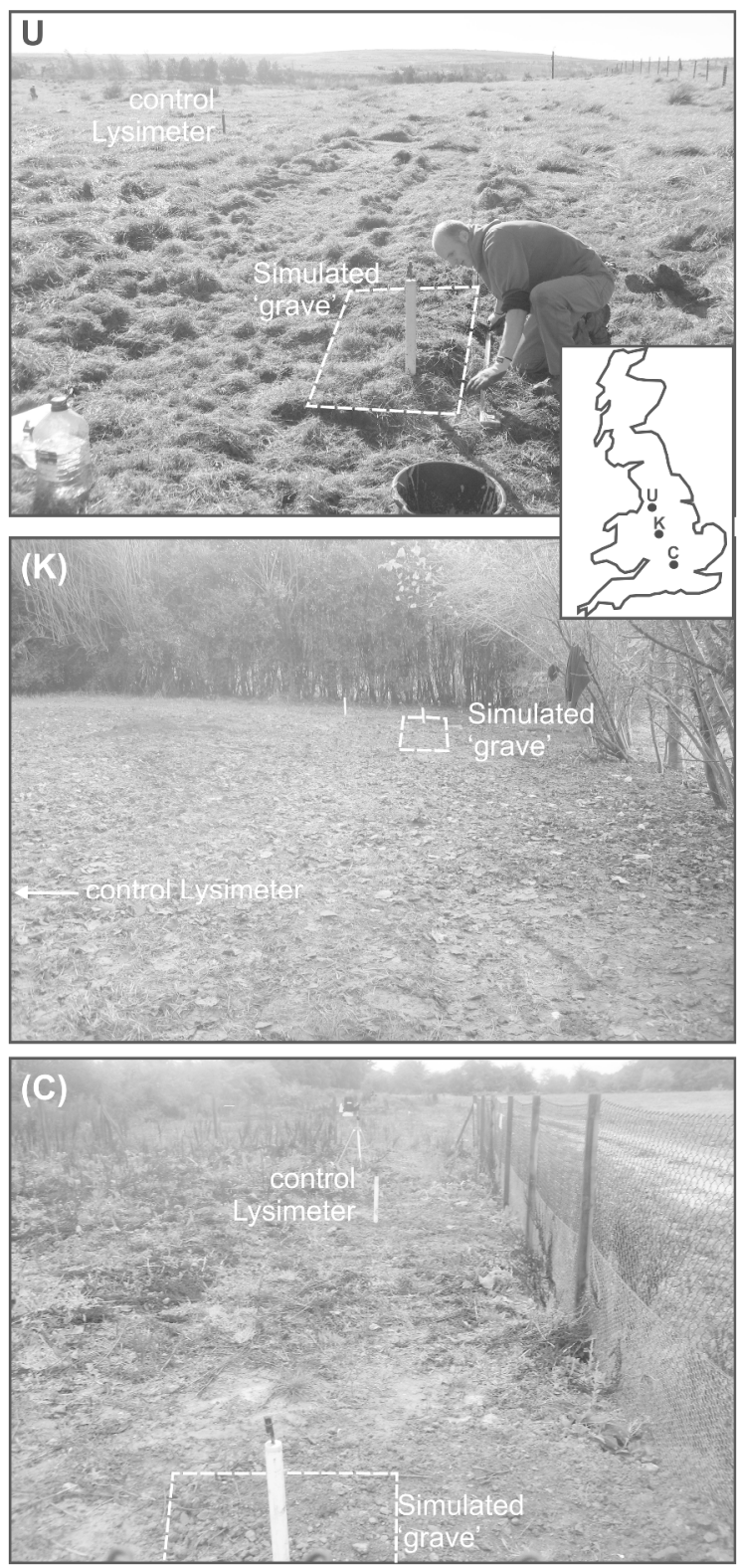

FIG. 2. Annotated photographs of the three test sites ( $U=U C L a n, K=$ Keele and $C=$ Cranfield Universities) with respective locations on U.K. map (inset). Respective simulated clandestine grave and control lysimeter positions also shown. 

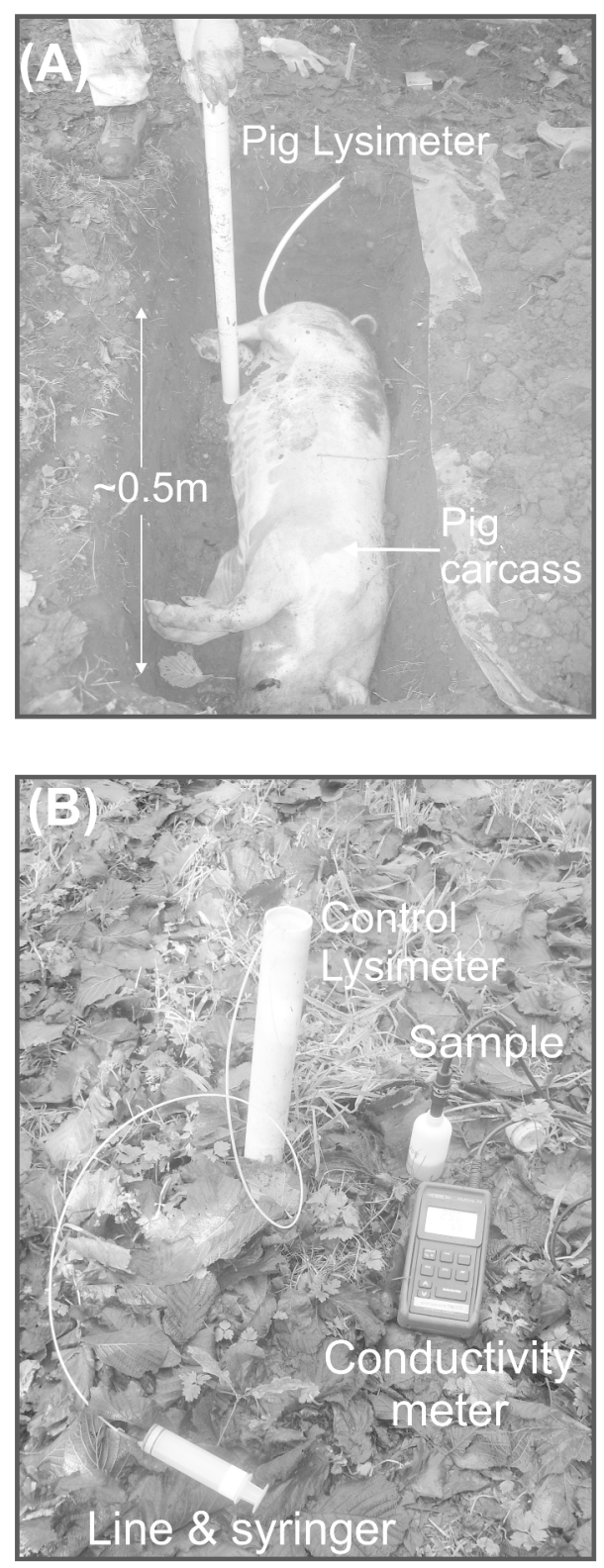

FIG. 3. Simulated clandestine burial annotated photographs from Keele study site of $(A)$ simulated grave contents and (B) fluid measuring accessories (see text). Modified from (27). 
FIG. 4. Graphical climate summary of rainfall (bars) and temperature (line) data from Keele University weather station, from our data and previously published data $(27,50)$. 
1

2

3

4

5

6

7

8

9

10

11

12

13

14

15

16

17

18

19

20

21

22

23

24

25

26

27

28

29

30

31

32

33

34

35

36

37

38

39

40

41

42

43

44

45

46

47

48

49

50

51

52

53

54

55

56

57

58

59

60
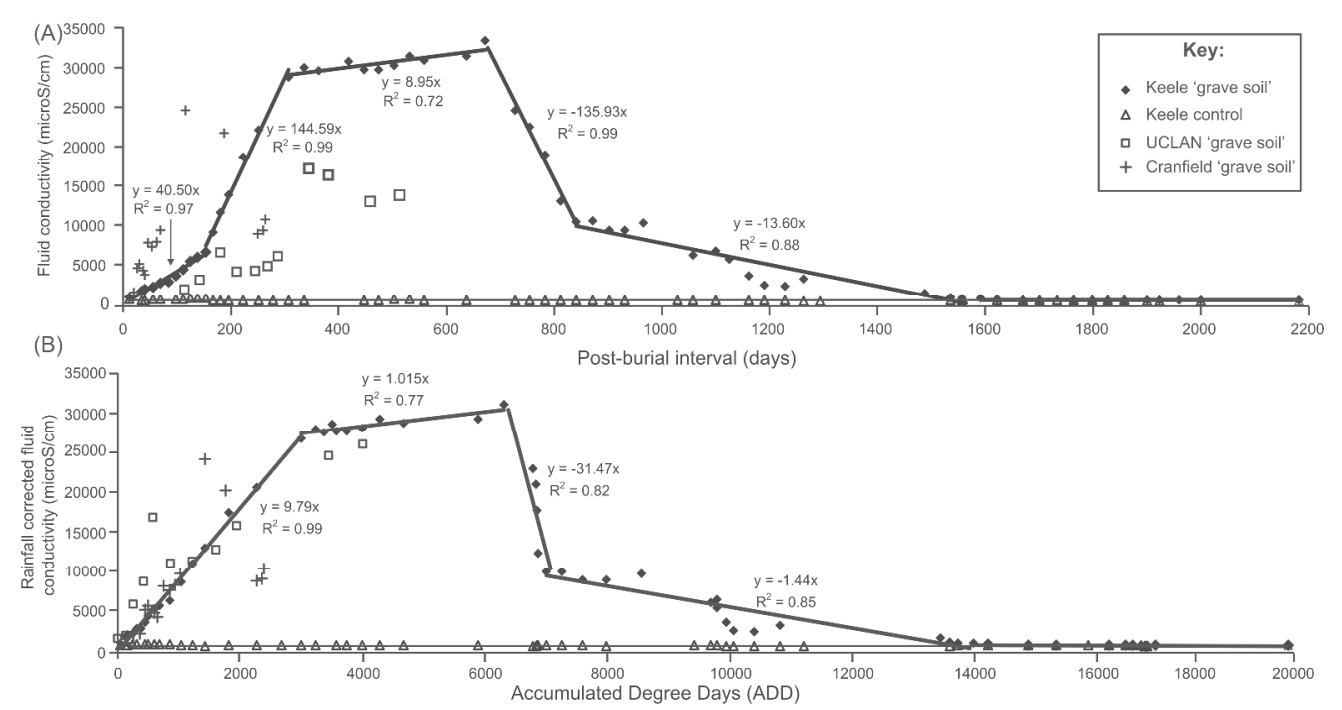

FIG. 5. Measured fluid conductivity results showing (A) Keele test site and (B) corrected for both temperature and monthly average rainfall (see text). Comparison data from Cranfield (crosses) and UCLan (squares) study sites also shown (see key). 
Soilwater Conductivity Analysis to Date and Locate Clandestine Graves of Homicide

Victims Soilwater conductivity analysis to-date clandestine graves -0 homicide

vietims*

Jamie K. Pringle, ${ }^{1}$ Ph.D.; John P. Cassella, ${ }^{2}$ Ph.D.; John R. Jervis, ${ }^{1}$ Ph.D.; Anna

Williams, ${ }^{3,4}$ Ph.D; Peter Cross, ${ }^{5}$ M.Sc; and Nigel J Cassidy, Ph.D ${ }^{1}$

${ }^{1}$ School of Physical Sciences \& Geography, Keele University, Keele, Staffordshire, ST4 6DA, U.K.

${ }^{2}$ Department of Forensic \& Crime Science, Staffordshire University, Leek Road, Stoke-on-Trent, Staffordshire, ST4 2DF, U.K.

${ }^{3}$ Cranfield Forensic Institute, Cranfield University, Shrivenham, Berkshire, SN6 8LA, U.K.

${ }^{4}$ now at School of Applied Sciences, University of Huddersfield, Queensgate, Huddersfield, Yorkshire, HD1 3DH, U.K.

${ }^{5}$ School of Forensic \& Investigative Sciences, University of Central Lancashire, Preston, Lancashire, PR1 2HE, U.K.

*Initial results were orally presented at the Second International Conference of Engineering Geophysics of the European Association of Geoscientists and Engineers in Al Ain, United Arab Emirates, 24-27 November 2013.

Sources of funding:

John R. Jervis's PhD research was jointly funded by the U.K.'s Engineering and Physical Sciences Research Council (EPSRC) and RSK STATS Geoconsult Limited. 
A 2007 Keele Innovation in Teaching Award (No. 67) part-funded the generation of the Keele test site. A Cranfield Defence and Security Teaching Fellowship funded the generation of the Cranfield site.

\begin{abstract}
In homicide investigations, it is critically important that Accurate determination of post-mortem interval-(PMI) and the time sincepost-burial interval (PMI/PBI) of-a elandestine grave of buried victims is determined accurately in a clandestine grave is critical importance to a murder investigationfor forensic investigators to link suspects to a crime or eliminate suspect(s)them from it. However, clandestine graves can be difficult to locate; Currently, and the detection rates worldwide are low using for a variety of search methods,-, (ranging from simple ground probing and use of scenttrained search dogs, through to more advanced remote imagingery analysis-and nearsurface geophysics) can be very lowtechniques. Here we show how long-term geoscience monitoring (6 years) of In this study, simulated elandestine graves of homicide victims were emplaced in three sites with contrasting soil types, bedrock and depositional environments. The long-term monthly in situ monitoring of grave soilwaterall revealed rapid increases in conductivity up to two years after burial-at all sites, with the longest study evidencing declining values to background levels after 4.25 years. Reonductivity of grave-soil decomposition fluids can be used to detect the presence of a buried cadaver. Measurements could also determine the post-buriat interval. Results were corrected for site temperatures and rainfall to allow-produce generic models s-of fluid conductivity as a function of time-time to be generated. The research suggest soilwater conductivity can give reliable, facilitating predictions of
\end{abstract}




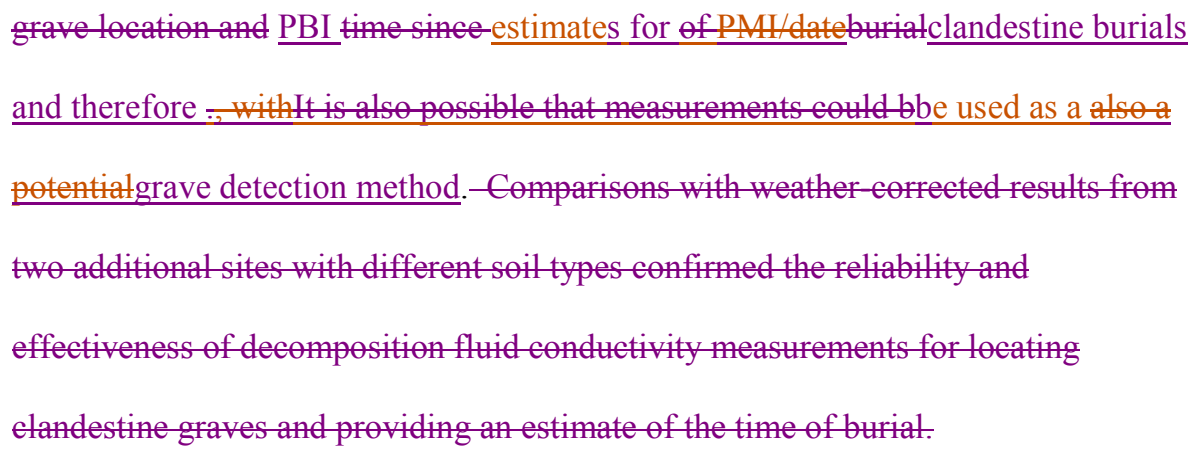

Keywords: forensic science, forensic geophysics, conductivity, clandestine burials, PMI, 
Geoscientific methods are being increasingly utilised by forensic search teams for the detection and location of clandestine burials (1-2). Clandestine graves of murder victims are usually shallow, less than $3 \mathrm{~m}$ and typically $0.5 \mathrm{~m}$ below ground level or bgl $(3,4)$, but current detection rates are low and, without locating the victim's body, obtaining a successful conviction is more difficult $(5, \underline{6})$. Search investigators will typically use a variety of methods, which include scenario-based, feature focused, intelligence-led and systematic Standard Operating Procedures (SOPs) $(\underline{5}, \underline{6})$. SOPs require investigators to follow sequential workflows, from reviewing case information, sourcing background / intelligence information and remote data analysis. This process occurs before determining search strategies, undergoing site reconnaissance and phased site investigations, and then intrusively investigating anomalous areas $(1, \underline{5,8})$. Geoscientific site investigation methods vary depending upon the specific case, search site and numerous other factors that are reviewed elsewhere (1), but can include scent-trained human remains detection dogs (7- $\underline{8})$, forensic geomorphology (9-10), forensic botany (11-12) and entomology (13-14), near-surface geophysics (1 $\underline{15}-\underline{22})$, intrusive probing $(\underline{10,23})$ and soil geoscience analysis (24-26).

\section{After a body has been found, it is natural for investigators to focus on determining} time since death. There has been extensive-taphonomy research on estimating the post-mortem interval (PMI) estimation-of very recently deceased individuals discovered above-ground that has been reviewed elsewhere is relatively well established-(27), commonly using body cadaver temperatures (28-29), entomology (30) and entomofauna (31) and thanatochemistry (32). For longer deceased individuals, other common PMI dating methods include tissue decomposition (33), skeletal remains (34) and tooth odontology (35). but the determination of both PMI of 
deceased individuals over longer time periods and importantly the post burial interval (PBI) of below ground individuals is at present poorly understood $(1,3,6)$.

Below-ground decomposition rates of discovered individuals has been shown to be highly variable (36), depending upon organic content (37), various local environmental factors such as soil type (38-41) and organism accessibility (42), amongst other factors to name but three, and note that the PMI may be different to the Post-Burial Interval (PBI). - These factors complicate the estimation of PMI for buried remains. Furthermore, it may useful to estimate the Post-Burial interval (PBI) as a guide to the PMI. However, the PMI and PBI may be different: a victim might not be buried immediately after death. In such cases, the PBI can be used as an estimate of the lower limit of the PMI.

The presence of a decomposing cadaver on the surrounding soil has also been shown to be detectable on the surrounding soil $\bar{j}_{2}$. fFor example, elevated levels of elements with respect to background values changes in soil chemistry $(24,25,37)$, such as changes in the levels of phosphates and nitrates (44), ninhydrin reactive nitrogen $(25,45)$, volatile organic compounds $(24,37,46)$ and $\mathrm{pH}(44,47)$ can all be detected. Changes in these soil properties can be used to estimate time since death. The decay of $\Theta$ other items such as materials associated with a grave have also been suggested to allow a PBI to be estimated $(39,48)$.

Although relatively poorly understood, 'grave soil' has been shown to be detectable by near-surface geophysical search methods, specifically electrical resistivity

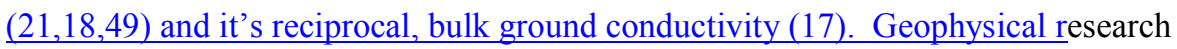
using simulated clandestine grave burials can provide critical information, for 
example, on optimal geophysical detection methods and equipment configurations $(\underline{15}, \underline{50-52})$, as well as providing continuous datasets for comparison with real cases (50,53-55). Recent research has found that electrical resistivity anomalies over burials are predominantly due to conductive fluids in grave soil that vary temporally $(27,50,56)$ that may be due to decomposition (Fig. 1). It has been shown that it is possible to repeatedly extract in situ decomposition fluids from both a buried pig cadaver and background soilwater, without the need for repeated disturbance or numerous replicantsreplicate samples as other authors have done. The resulting fluids can be simply analysed for conductivity using a hand-held meter, with initial results of a pilot two year monitoring study showing promise (27).

This-The aim of this was study was to expand the work of Pringle et al.- (27). fFirstly aimed the aim was to obtain long-term (6 years) in situ grave soil water conductivity monitoring data of for a U.K. simulated clandestine burial. Results willwere then be used to generate linear regression curves to correlate measurements against PBI.

Secondly the same experiment will bewas conducted over a shorter time period at two other U.K. academic study sites to assess the method's robustness and variability in different soil and bedrock types. Thirdly, all results will bewere verified by corrected for local major climate variations (temperature and rainfall) to allow direct comparisons forwith other studies, and to allow search teams to utilise this method. and then comparing datasets collected using the same methodology at wo other U.K. academic study sites. Fourthly, and finally the potential for detecting clandestine burials using this method is diseussedwas assessed. 


\section{Methodology}

Study test sites

Three U.K. University test sites in different parts of the country were employed for this study, all in temperate climates that were typical of the U.K.

The University of Central Lancashire (UCLan) test site in Lancashire was situated in a dedicated research facility off campus in a rural environment on peat moorland (Fig. 2). The site lies $\sim 300 \mathrm{~m}$ above sea level. The local soil was determined onsite to be a dark brown, organic-rich hill peat with interbeds of silt and sand. Nearby records (57) indicated the Carboniferous (Westphalian) Pennine Lower Coal Measures Formation comprising a mixture of sandstone, mudstone and coal bedrock was present at least 4 $\mathrm{m}$ below ground level (bgl). This site has been used for several decomposition studies prior to this $(\underline{58,59})$, albeit spatially far enough away and downslope of the area to prevent any potential contamination issues; initial 'grave' soilwater conductivity values were also the same as for the control.

The Keele University test site in Staffordshire was situated in a restricted area in grassed semi-rural ground surrounded by deciduous woodland and hedges (Fig. 2). The site lies $\sim 200 \mathrm{~m}$ above sea level. The local soil was determined onsite to be a sandy loam with nearby borehole records (27) indicating the Carboniferous (Westphalian) Butterton Sandstone bedrock was present $\sim 2.5 \mathrm{~m}$ bgl. This site has

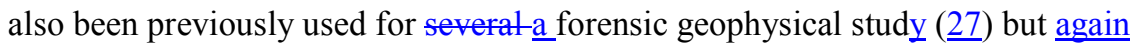
earlier simulated burialsthese were situated far enough away and downslope to avoid any potential contamination issues; initial 'grave' soilwater conductivity values were 
also the same as for the control. The preliminary two years of results were published (27).

\section{The Cranfield University test site in Oxfordshire-Wiltshire was situated in a restricted} area on the Shrivenham campus in cleared semi-urban ground surrounded by deciduous woodland and hedges (Fig. 2). The site lies $\sim 80 \mathrm{~m}$ above sea level. The local soil was determined to be a mixed made-ground and sandy loam with nearby records (6ㅁ) indicating Jurassic Oxford Clay Formation and Corallian Limestone bedrock both present at shallow depths bgl. The site had not been used for previous decomposition studies.

\section{Simulated graves}

For consistency, the simulated graves at all three sites (Fig. 2) were created following the same method, albeit at different dates $(08 / 12 / 2007$ for Keele University, 12/10/2010 for UCLan and 18/08/2011 for Cranfield Universities respectively). Each $\sim 2 \mathrm{~m} \mathrm{x} \sim 0.5 \mathrm{~m}$ grave was hand-excavated to $0.5 \mathrm{~m}$ below ground level (bgl), the respective $(\sim 80 \mathrm{Kkg})$ pig (Sus scrofa) cadavers, which had been sourced from local abattoirs and dead for less than $12 \mathrm{~h}$ at the time of burial, were then placed within the Formatted: Font: Italic graves. Simulated grave depths were based on published data on average depths of discovered human clandestine burials (87 in the U.S. (4) and 29 in the U.K. (ㅁ) respectively). The use of pig cadavers as human analogues is well established in forensic science studies as they have similar chemical compositions, body sizes, tissue:body fat ratios, and skin/hair type to humans $(\underline{50}, \underline{41,61})$. The use of pig cadavers at these sites had been approved by DEFRA and the respective University Ethics Committees. 
A soilwater sample lysimeter was placed within each grave between the pig cadaver and the grave wall (Fig. 3). The porous end cap of each model 1900 (SoilMoisture Equipment Corporation ${ }^{\mathrm{TM}}$ ) soilwater lysimeter wasere vertically inserted into a mixture of water and excavated soil which ensured good hydraulic conductivity between the grave and the lysimeter following standard practice $(\underline{62})$. The simulated graves were then back-filled using the excavated soil and the overlying grass sods were then replaced. Control site lysimeters were installed $\sim 10 \mathrm{~m}$ away from each grave by digging narrow holes $(\sim 0.3 \mathrm{~m} \mathrm{x} \sim 0.3 \mathrm{~m})$ to $\sim 0.5 \mathrm{~m} \mathrm{bgl}$ and following the sample lysimeter emplacement procedure described above. These control lysimeters were placed far enough away and up-slope of the simulated graves to avoid any potential contamination with grave fluid (Fig. 2). Once installed, the exposed top of each lysimeter were was sealed with a rubber stopper (Fig. 3) and a vacuum pump was employed to generate the established lysimeter suction of $65 \mathrm{KPa} 13$, in order for the instrument to draw fluid from the surrounding soil.

\section{Sample collection and measurements}

Two days before a sample was extracted, rubber stoppers from the respective lysimeters were removed and any fluid present extracted using a plastic syringe with a narrow tube attachment. This was to ensure that the analysed fluid had an accurate post-burial date when measured. The lysimeters were then resealed and repressurised as previously described. On the day of sampling (usually monthly, see Tables 1-3), the extraction procedure was repeated but any fluid was placed in a labelled plastic sample bottle; a portable WTW Instrument multi-line P4 temperaturecalibrated conductivity meter (6) was then immediately placed in the bottle and three 
conductivity values obtained; an average was therefore derived (Fig. 3). If no sample was present, this was recorded.

\section{Climatological data}

The closest weather stations run by the U.K. Meteorological Office were used to obtain average daily rainfall and air temperature readings over the respective monitoring periods (Tables 1-3). These were situated $\sim 2.4 \mathrm{~km}$ (Bacup), $\sim 0.2 \mathrm{~km}$ (Keele), and $\sim 3 \mathrm{~km}$ (Sevenhampton) away from the UCLan, Keele and Cranfield University study sites respectively. Keele University operates the Keele meteorological weather station which is close to the study site and recorded temperate weather patterns (Fig. 4). It recorded monthly minimum, maximum and average total rainfall of $2.6 \mathrm{~mm}, 167 \mathrm{~mm}$ and $64 \mathrm{~mm}$ respectively over the 2,004 day study period. The corresponding values recorded for UCLan were $23 \mathrm{~mm}, 278 \mathrm{~mm}$ and $126 \mathrm{~mm}$ respectively over the 610 day study period. Cranfield recorded $17 \mathrm{~mm}, 138 \mathrm{~mm}$ and $68 \mathrm{~mm}$ respectively over the 475 day study period.

The daily average temperatures from each site were used to convert post-burial days to Accumulated Degree Days (ADDs) (see 37). ADDs correct for local site temperature variations by weighting each day by the average daily temperature and then giving each burial day an ADD value. Therefore, for a 2-day period, in which the average temperature of the first day was $12{ }^{\circ} \mathrm{C}$ and the second day was $15^{\circ} \mathrm{C}$, the ADD value for those 2 days would be 27 ADDs. Tables 1-3 summarises these datasets. 
Calculated monthly total rainfall $(\mathrm{mm})$ data from all three sites were also used to obtain yearly monthly rainfall averages as well as obtaining yearly monthly rainfall averages for England over the study period from the U.K. Meteorological Office. Table 4 lists these datasets. The rainfall datasets were used to correct the measured soilwater measurements for local rainfall variation; conductivity values were multiplied by a rainfall correction factor, which was calculated by dividing the average monthly rainfall for England in a given year by the average monthly rainfall for the local area in the same year. Correction for rainfall was important as relatively high rainfall rates could potentially dilute grave soil water and hence reduce the measured conductivity values, and relatively low rainfall rates would effectively concentrate grave soil water and hence increase measured conductivity values. 
Results

The main field soilwater measurement results from the Keele test site (Fig. 5A) evidenced consistent background conductivity values over the 2,004 day study period (averaging $411 \pm 0.1 \mathrm{mS} / \mathrm{cm}$ ). The grave conductivity values (see Table 1) rapidly increased from $266 \pm 0.1 \mathrm{mS} / \mathrm{cm}$ (12 days) up to $28,800 \pm 0.1 \mathrm{mS} / \mathrm{cm}$ (307 days) before gradually increasing to a maximum of $33,400 \pm 0.1 \mathrm{mS} / \mathrm{cm}$ (671 days). Measured grave conductivity then rapidly decreased to $10,460 \pm 0.1 \mathrm{mS} / \mathrm{cm}(840$ days) before gradually decreasing to typical background values of $499 \pm 0.1 \mathrm{mS} / \mathrm{cm}$ (1,621 days) until the end of the study period (2,004 days). These grave conductivity changes could be grouped into six linear regressions with a good fits $\left(\mathrm{R}^{2}\right.$ values of

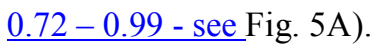

The field soilwater measurement results from the UCLAN test site (Fig. 5A) evidenced consistent background conductivity values over the 511 day study period (averaging $331 \pm 0.1 \mathrm{mS} / \mathrm{cm}$ ). The grave conductivity values (see Table 2 ) rapidly increased from $570 \pm 0.1 \mathrm{mS} / \mathrm{cm}$ (12 days) up to $17,300 \pm 0.1 \mathrm{mS} / \mathrm{cm}$ (344 days), albeit being relatively constant at $\sim 5,000 \pm \mathrm{mS} / \mathrm{cm}$ between 181 to 287 days PBI. 
Measured grave conductivity then gradually decreased to $14,000 \pm 0.1 \mathrm{mS} / \mathrm{cm}$ at the end of the study period (511 days). A few monthsSamples were not collected during a few months of the study period but this did not affect the overall trends.

The field soilwater measurement results from the Cranfield test site (Fig. 5A) evidenced consistent background conductivity values over the 264 day study period (averaging $829 \pm 0.1 \mathrm{mS} / \mathrm{cm}$ ). The grave conductivity values (see Table 3 ) rapidly increased from $674 \pm 0.1 \mathrm{mS} / \mathrm{cm}$ (22 days) up to $24,625 \pm 0.1 \mathrm{mS} / \mathrm{cm}$ (117 days), before rapidly decreasing to $10,987 \pm \mathrm{mS} / \mathrm{cm}$ at the end of the study period (264 days). Again, samplesA few months were not collected during some months of the study period but this did not affect the overall trends.

At Eeach local study site, there were local temperature variations, which directly impact affected decomposition rates (4), and these variations were removed from raw conductivity values by converting Post-Burial (day) Interval (PBI) to Accumulated Degree Days (ADD), as detailed in the methods. Local study site rainfall variations, (which impactseffect conductivity values as relative higher rainfall rates will reduce measured conductivities, ) were also removed by calculating each of the the respective site's monthly average rainfall during the study and then correcting these by percentage changes against the of test sites from England-average monthly rainfall for England (Table 4). The resulting climate-corrected Keele site data showed a much

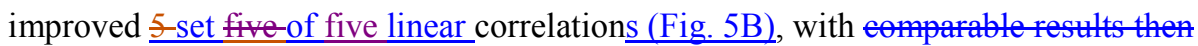
derived from the other two study sites also showing a good comparison ofsimilar conductivity results with the Keele study results over the same post-burial time periods (Fig. 5B). This method also accounted for the different respective study start dates (December 2007, October 2010 and August 2011 for the Keele, UCLAN and 
$\underline{\text { Cranfield studies respectively) and their associated seasonal local climate variations }}$ buried at different times of the yearburied at different times of the year (Fig. 5B).

\section{Discussion}

Every search for a murder victim in a clandestine burial is unique: the conditions (e.g. the local soil type, vegetation, climate and potential depositional environment) and factors relating to the burial (e.g. the victim's body size, burial depth bgl and season of deposition) will vary from case to case $(1, \underline{3,4,50})$. These factors will affect both successful detection of a clandestine burial and the determination of the PBI; the latter has, to-date, proved difficult to estimate when a grave is discovered $(37,63,64)$. Nevertheless, forensic search teams have an obligation "to use any means at their disposal to find [a body]" (므. When victims have been missing for a long period of time, it becomes even more of a challenge, as seen, for example, with the forensic high profile and ongoing U.K. search for Keith Bennett since his disappearance in 1964 $(\underline{65)}$.

These three studies haves also been demonstrated here that measuring 'grave' soilwater conductivity it is a relatively robust geoscientific method to-for estimating ebtain-a PBI-date of a discovered clandestine burial up to $\sim 1,600$ days / 13,500 ADDs after burial, if local temperature and rainfall data are available to correct measured values. The importance of correcting measured conductivity values for local rainfall and temperature information has also been shown by -this study to be critical from this study(Fig. 4). It is difficult with current methods to estimate a PBI after an individual is skeletonised $(1,3,27)$ and this proposed simple method may thus prove very beneficial to-analyse by forensic recovery teams. Comparison of a pilot 
(66) and this study's preliminary (27) results has also noted that cadaver size did not have a significant effect on measured 'grave' soilwater conductivity measurements.

To test whether this could be used as a datingThe potential of this PBI estimation method, this was demonstrated with an early simulated clandestine burial study (27), where a domestic pig cadaver was 'discovered', the measured conductivity value for a 'discovered' buried pig cadaver resulting resulted in a $\sim 10 \%$ date discrepancy

between calculated and actual PBI over the 6 monthly monitoring period. It should be noted that a measured conductivity value could potentially give two PBI burial dates (cf. Fig. 5); but this may be still narrow down the PBI and may be more information than forensic investigators would otherwise have.

As the same experimental method was utilised Having conducted the same experiment inat three U.K. study sites, on different sites-with different local soil types, depositional environments and elimates-weather conditions over different temporal periods, and thebut still having obtained reliable geoscience dataset were still found to be reliable, the method described findings gives confidence that it the methodology used is robust. Note however that there was some variability between comparable corrected results with the three study sites, which may be due to the differing depositional environments and soil types.

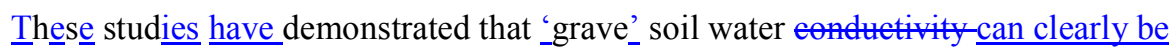
$\underline{\text { differentiated from background soilwater by measuring soilwater conductivities and }}$ $\underline{\text { therefore this technique has }}$ the potential to also be a useful clandestine grave detection method. This dataset shows clear grave soil conductivity changes over time, with the most rapid changes occurring from burial up to $~ 300$ days / 3,000 ADDs 
after burial. This change is most likely due to decomposition changes $(\underline{4}, \underline{33})$ (Fig. 1).

Forensic search teams could potentially detect clandestine graves by eitherinitially measuring conductivities in surface water downslope / downstream of identified potential burial site(s) as (5) and (2) have undertaken in their respective forensic searches. This would obviouslyalso require a programme of water sampling all around the identified potential burial site(s) in order to gain sufficient background conductivity readings to allow potential sites to be confirmed/not prioritisedidentified using this detection method. Whilst surface water sampling is relatively $\underline{\text { straightforward and commonly undertaken in environmental contamination surveys }}$ (1), forensic soilwater surveys would involve a significant amount of effort, from initial soil sampling of suspected burial sites and careful storage, to and/or by undertaking a geoscience soil survey programme over search area(s) and, after to centrifuging to extract soilwater (25), and measuring their respective conductivity values to identify anomalous readings. This therefore would not be recommended as an initial search method; rather it should be undertaken when identified site(s) have been located-a search area has been narrowed down to an appropriate size. This does, however, have promise as other studies have shown decomposition fluids to be retained in the local soil environment and areto be electrically detectable, even when physical remains have decayed (드).

Remaining unknown variables will be ease-case-specific, but could include any delay between death and burial (e.g. storage), style of burial ( $\underline{50})$ and removal and reburial of the body or bodies $(\underline{68})$. Other decomposing remains (e.g. animal burialscadavers) may also interfere with results. The proposed method could also be applied to determine the post-burial interval for other organic material, for example, illegal animal burials (무) or landfill leachate plumes (1). 


\section{Conclusions and further work}

This long-term research project regularly extracted soilwater from athree simulated clandestine burials in different soil and bedrock types and depositional environments in the UK. This and has produced a datasets of temporally varying conductivities over the 6 years, monitoring periodevidencing relative rapid increasing of 'grave' soilwater conductivities up to 2 years post-burial, before declining to background conductivity values after 4.25 years of burial. Local climate variations of temperature and rainfall have been corrected for and comparable results have been obtained from the three other sites using the same methodology in contrasting local depositional environments and soil types-which gives confidence in the method. Analysing soilwater conductivities of a discovered clandestine grave in the fieldsitu would be Formatted: Font: Italic relatively simple and could provide an estimate of both PMI andthe PBI for forensic search teams although this may be different to the PMI. Note that discovered burials may plotted on the conductivity graphs may suggest two possible PBI valueen two positions on the conductivity graphs. The method could also potentially be used as a search tool if multiple soilwater and/or surface water samples are collected and analysed. This proposed method could also be applied to estimate the post-burial intervaltime burial of of other organic material, such as illegal animal burials or $\underline{\text { landfill plumes. }}$

Further work should clearly first test this potential PBI method in a real forensic case of a discovered clandestine grave in order to determine its usefulness for forensic investigators. Secondly, it is important that the experiment is replicated in other soil types in order to quantitatively understand how this important variable affects the 
soilwater conductivity results. Thirdly, analytical chemical techniques should be

utilised to examine the soilwater water samples. This would hopefully clarify the chemical changes that cause the variations in soilwater conductivity that were measured in this studywhere there is a clearly observed temporal change in conductivity that will be related to decomposition. It may also determine if whether individual elements, compounds or acids could be used as-a complimentary dating technique(s). Fourthly, and finally, this experiment should be replicated using human cadavers as this may be a variable to consider. 


\section{Acknowledgements}

We acknowledge Tim Millington and Malcolm Wright for assistance in creating the study site and Ian Wilshaw for assistance in installing the lysimeters and providing local Keele weather data. The UK Metereological office is also thanked for providing weather data for the other test sites. The authors also wish to thank the numerous physical science under- and post-graduate students for undertaking pilot investigative projects. 


\section{References:}

1. Pringle JK, Ruffell A, Jervis JR, Donnelly L, Hansen J, Morgan R, et al.Pirrie D, Harrison M, The use of geoscience methods for terrestrial forensic searches. Earth Sci Rev 2012;114:108-123.

2. Ruffell A, McKinley J. Geoforensics. Chichester: Wiley, 2008.

3. Hunter J, Cox M. Forensic archaeology: advances in theory and practice. Abingdon, VA: Routledge, 2005.

4. Manhein MH. Decomposition rates of deliberate burials: a case study of preservation. In: Haglund WD, Sorg MH, editors. Forensic taphonomy: the postmortem fate of human remains, Boca Raton: CRC, 1996;469-81.

5. Harrison M, Donnelly LJ. Locating concealed homicide victims: developing the role of geoforensics. In: Ritz K, Dawson L, Miller D, editors. Criminal and Environmental Soil Forensics, Dordrecht: Springer, 2009;197-219.

6. Larson DO, Vass AA, Wise $\mathrm{M}_{-\overline{5}}$ Advanced scientific methods and procedures in the forensic investigation of clandestine graves. J Cont Crim Jus 2011;27:149—182.

7. Lasseter A, Jacobi KP, Farley R, Hensel L. Cadaver dog and handler team capabilities in the recovery of buried human remains in the Southeastern United States. J For Sci 2003;48:1-5. 
$\underline{\text { 8. Dupras TL, Schultz JJ, Wheeler SM, Williams LJ. Forensic recovery of human }}$ remains. Boca Raton: CRC Press, 2006.

9. Ruffell A, McKinley J. Forensic geomorphology. Geomorphology 2014;206:14-22.

10. Killam EW. The detection of human remains. SpringfieldUSA: Charles C. Thomas, 2004.

11. Aquila I, Ausania F, Di Nunzio C, Serra A, Boca S, Capelli A, et al. The role of forensic botany in crime scene investigation: case report and review of literature. J

For Sci 2014; DOI: 10.1111/1556-4029.12401

12. Coyle HM. Forensic botany: principles and applications to criminal casework. Boca Raton: CRC Press, 2005.

13. Gennard D. Forensic entomology: an introduction. $2^{\text {nd }}$ ed, Chichester: WileyBlackwell, 2012.

14. Amendt J, Campobasso CP, Gaudry E, Reiter C, LeBlanc HN, Hall MJR. Best practice in forensic entomology: standards and guidelines. Int J Legal Med 2007;121:90-104.

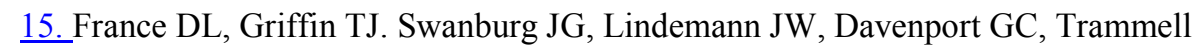
V. et al. A multidisciplinary approach to the detection of clandestine graves. J For Sci $1992 ; 37: 1445-58$. 
16. Powell K. Detecting human remains using near-surface geophysical instruments. Expl Geophys 2004;35:88-92.

17. Nobes DC. The search for "Yvonne": a case example of the delineation of a grave using near-surface geophysical methods. J For Sci 2000;45:715-21.

18. Pringle JK, Jervis JR. Electrical resistivity survey to search for a recent clandestine burial of a homicide victim, UK. For Sci Int 2010;202(1-3):e1-7.

19. Novo A, Lorenzo H, Ria F, Solla M. 3D GPR in forensics: finding a clandestine grave in a mountainous environment. For Sci Int 2011;204:134-8.

20. Schultz JJ. Using ground-penetrating radar to locate clandestine graves of homicide victims: forming forensic archaeology partnerships with law enforcement. Homicide Stud 2007;11:15-29.

21. Cheetham P. Forensic geophysical survey. In: Hunter J, Cox, M, editors. Forensic archaeology: advances in theory and practice. Abingdon: Routledge, 2005:62-95.

22. Witten A, Brooks R, Fenner T. The Tulsa Race Riot of 1921: a geophysical study to locate a mass grave. Leading Edge 2001;20:655-60.

23. Owsley DW. Techniques for locating burials, with emphasis on the probe. J For Sci 1995;40:735-740. 
24. Vass AA, Smith RR, Thompson CV, Burnett MN, Dulgerian N, Eckenrode BA.; Odor analysis of decomposing human remains. J For Sci 2008;53:384-391.

25. Carter DO, Yellowlees D, Tibbett M. Using ninhydrin to detect gravesoil. J For Sci 2008;53:397-400.

26. Dekeirsschieter J, Verheggen FJ, Gohy M, Hubrecht F, Bourguignon, L, Lognay G, et alHaubruge E. Cadaveric volatile organic compounds released by decaying pig carcasses (Sus domesticus) in different biotopes. For Sci Int 189;2009:46-53.

27. Pringle JK, Cassella JP, Jervis JR. Preliminary soilwater conductivity analysis to date clandestine burials of homicide victims. For Sci Int 2010;198:126-33.

28. Marshall TK. Estimating the time of death: the use of the cooling formula in the study of post-mortem body cooling. J For Sci 1962;7:189-210.

29. Henssge C. Death time estimation in case work. The rectal temperature time of death nomogram. For Sci Int 1988;38:209-36.

30. Arnaldos M, Garcia I, Romera E, Presa JJ, Luna A, Estimation of post-mortem $\underline{\text { interval in real cases based on experimentally obtained entomological evidence, For }}$ $\underline{\text { Sci Int 2005;149:57-65. }}$

31. Marchenko MI, Medicolegal relevance of cadaver entomofauna for the determination of the time of death, For Sci Int 2001;120:89-109. 
32.Madea B, Is there recent progress in the estimation of the post-mortem interval by means of thanatochemistry? For Sci Int 2005;151:139-49.

33. Janaway RC, Percival SL, Wilson A. Decomposition of human remains. In: Percival SL, editor. Microbiology and Aging: Clinical Manifestations: New York: Springer, 2009:13-334.

34. Ramsthaler F, Kreutz K, Zipp K, Verhoff MA. Dating skeletal remains with luminol-chemiluminescence: validity, intra- and inter-observer error, For Sci Int 2009;187:47-50.

35. McKeown AH, Bennett JL. A preliminary investigation of postmortem tooth loss, J For Sci 1995;40:755-57.

36. Rodriguez WC. Decomposition of buried and submerged bodies, In: Haglund WD, Sorg MH editors. Forensic Taphonomy: The Postmortem Fate of Human Remains. Boca Raton: CRC Press, 1997:459-68.

37. Vass AA, Bass WM, Wolt JD, Foss JE, Ammons JT. Time since death determinations of human cadavers using soil solution. J For Sci 1992;37:1236-53.

38. Forbes SL, Dent BB, Stuart BH, The effect of the burial environment on adipocere formation. For Sci Int. 2005;154:24-34. 
39. Wilson AS, Janaway RC, Holland AD, Dodson HI, Barran E, et al. Modelling the buried human body environment in upland climes using three contrasting field sites. For Sci Int 2007;169:6-18.

40. Turner B, Wiltshire P. Experimental validation of forensic evidence: a study of the decomposition of buried pigs in heavy clay soil. For Sci Int 1999;101:113-22.

41. Carter DO, Tibbett M. Cadaver decomposition and soil: processes. In: Tibbett M, Carter DO, editors. Soil Analysis in Forensic Taphonomy: Chemical and Biological Effects of Buried Human Remains. Boca Raton: CRC Press, 2009;29-52.

42. Hopkins DW, The role of soil organisms in terrestrial decomposition, In: Tibbett M, Carter DO, editors. Soil Analysis in Forensic Taphonomy: Chemical and Biological Effects of Buried Human Remains. Boca Raton: CRC Press, 2009;53-66.

43. Davla M, Kalácska M, Moore TR, Costopopoulos A. Detecting graves with methane. Geoderma 2012;189-190:18-27.

44. Matias MJ, Marques da Silva M, Goncalves L, Peralta C, Grangeia C, et al. An investigation into the use of geophysical methods in the study of aquifer contamination by graveyards. Near Surf Geophys;2:131-6.

45. Van Belle LE, Carter DO, Forbes SL. Measurement of ninhydrin reactive nitrogen influx into gravesoil during aboveground and belowground carcass (Sus domesticus) decomposition. For Sci Int 2009;193:37-41. 
47. Benninger LA, Carter DO, Forbes SL. The biochemical alteration of soil beneath a decomposing carcass. For Sci Int 2008;180:70-5.

48. Janaway RC. Decomposition of materials associated with buried cadavers. In: Tibbett M, Carter DO, editors. Soil Analysis in Forensic Taphonomy: Chemical and Biological Effects of Buried Human Remains. Boca Raton: CRC Press, 2009;153201.

49. Hansen JD, Pringle JK, Goodwin J. GPR and bulk ground resistivity surveys in graveyards: locating unmarked burials in contrasting soil types. For Sci Int 2014;237:e14-29.

50. Pringle JK, Jervis JR, Hansen JD, Cassidy NJ, Jones GM, Cassella JP. Geophysical monitoring of simulated clandestine graves using electrical and ground penetrating radar methods: 0-3 years. J For Sci 2012;57:1467-86.

51. Schultz JJ, Martin MM. Controlled GPR grave research: comparisons of reflection profiles between 500 and $250 \mathrm{MHz}$ antennae. For Sci Int 2011;209:64-9.

52. Pringle JK, Jervis J, Cassella JP, Cassidy NJ, Time-lapse geophysical investigations over a simulated urban clandestine grave. J For Sci 2008;53:1405-17. 
53. Schultz JJ, Martin MM. Monitoring controlled graves representing common burial scenarios with ground penetrating radar. J App Geophys 2012;83:74-89.

54. Schultz JJ. Sequential monitoring of burials containing small pig cadavers using ground-penetrating radar. J For Sci 2008;53:279-87.

55. Schultz JJ, Collins ME, Falsetti AB. Sequential monitoring of burials containing large pig cadavers using ground-penetrating radar. J For Sci 2006;51:607-16.

56. Jervis JR, Pringle JK, Tuckwell GW. Time-lapse resistivity surveys over simulated clandestine graves. For Sci Int 2009a;192:7-13.

57. E. Hough, Geology of the Burnley area (SD82NW and SD83SW), British Geological Survey Internal Report WA/00/30 (2004). Available online at: http://nora.nerc.ac.uk/20026/1/WA_00030_Burnley.pdf Last accessed 21st June 2013.

58. Simmons T, Cross PA, Adlam RE, Moffat, C. The influence of insects on decomposition rate in buried and surface remains. J For Sci 2010;44:889-892.

59. Gruenthal A, Moffatt C, Simmons T. Differential decomposition patterns in charred versus un-charred remains. J For Sci 2012;57:13-18.

60. Birbeck, V. Excavations at Watchfield, Shrivenham, Oxfordshire. Wessex Archaeology, 1998. 
61. Stokes KL, Forbes SL, Tibbett M. Human versus animal: contrasting decomposition dynamics of mammalian analogues in experimental taphonomy. J For Sci 2013;58:583-591.

62. Grossman J, Udluft P. The extraction of soil water by the suction-cup method: a review. J Soil Sci 1991;42:83-93.

63. Carter DO, Yellowlees D, Tibbett M. Temperature affects microbial decomposition of cadavers (Rattus rattus) in contrasting soils. Appl Soil Ecol 2008;40:129-437.

64. Breitmeier D, Graefe-Kirci U, Albrecht K, Weber N, Tröger HD, Kleeman WJ. Evaluation of the correlation between time corpses spent in in-ground graves and findings at exhumation. For Sci Int 2005;154:218-223.

65. Fenning PJ, Donnelly LJ. Geophysical techniques for forensic investigation. Geol Soc London Spec Pub 2004;232:11-20.

66. Jervis JR, Pringle JK, Cassella JP, Tuckwell GT. Using soil and groundwater to understand resistivity surveys over a simulated clandestine grave. In: Ritz K, Dawson $\underline{\text { L, Miller D, editors. Criminal and environmental soil forensics. Dordrecht, The }}$ Netherlands: Springer, 2009;271-84.

67. Juerges A, Pringle JK, Jervis JR, Masters P. Comparisons of magnetic and electrical resistivity surveys over simulated clandestine graves in contrasting burial environments. Near Surface Geophys 2010;8:529-539. 
68. Brown AG. The use of forensic botany and geology in war crimes investigations in NE Bosnia. For Sci Int 2006;163:204-z10.

69. Ruffell A, Kulessa B. Application of geophysical techniques in identifying illegally buried toxic waste. Env For 2009;10:196-207. 
1

2

3

4

5

6

7

8

9

10

11

12

14

15

16

17

18

19

20

21

22

23

24

25

26

27

28

29

30

31

32

33

34

35

36

37

38

39

40

41

42

43

44

45

46

47

48

49

50

51

52

53

54

55

56

57

58

59

60
Additional information and reprint requests:

Jamie K. Pringle, Ph.D.

School of Physical Sciences \& Geography

William Smith Building

Keele University

$\underline{\text { Keele }}$

$\underline{\text { Staffordshire ST5 5BG }}$

U.K.

E-mail: j.k.pringle@keele.ac.uk 


\section{FIGURE CAPTIONS:}

FIG. 1. Four main clandestine burial decompositional stages. (A) Recent burial, surface expression is most obvious. (B) Early decomposition with search dogs and/or methane probes being optimal. (C) Late-stage decomposition with grave soil fluids. (D) Final skeletonised decomposition. Modified from (1).

FIG. 2. Annotated photographs of the three test sites $(\mathrm{U}=\mathrm{UCLan}, \mathrm{K}=$ Keele and $\mathrm{C}=$ Cranfield Universities) with respective locations on U.K. map (inset). Respective simulated clandestine grave and control lysimeter positions also shown.

FIG. 3. Simulated clandestine burial annotated photographs from Keele study site of (A) simulated grave contents and (B) fluid measuring accessories (see text). Modified from $(\underline{27})$.

FIG. 4. Graphical climate summary of rainfall (bars) and temperature (line) data from Keele University weather station, from our data and previously published data $(\underline{27,50})$.

FIG. 5. Measured fluid conductivity results showing (A) Keele test site and (B) corrected for both temperature and monthly average rainfall (see text). Comparison data from Cranfield (crosses) and UCLan (squares) study sites also shown. 


\section{TABLES}

\begin{tabular}{|c|c|c|c|c|c|}
\hline $\begin{array}{c}\text { Sample } \\
\text { date }\end{array}$ & $\begin{array}{c}\text { Post- } \\
\text { burial } \\
\text { days / } \\
\text { interval } \\
\text { (PBI) }\end{array}$ & $\begin{array}{l}\text { Accum- } \\
\text { ulated } \\
\text { Degree } \\
\text { Days } \\
\text { (ADD) }\end{array}$ & $\begin{array}{c}\text { Field- } \\
\text { measured } \\
\text { 'grave' } \\
\text { conductivity } \\
(\mathrm{mS} / \mathrm{cm})\end{array}$ & $\begin{array}{c}\text { Rainfall } \\
\text { england- } \\
\text { corrected } \\
\text { grave } \\
\text { conductivity }\end{array}$ & $\begin{array}{c}\text { Field- } \\
\text { measured } \\
\text { 'control' } \\
\text { conductivi } \\
(\mathrm{mS} / \mathrm{cm})\end{array}$ \\
\hline 08/12/2007 & 0 & 0 & & & \\
\hline $19 / 12 / 2007$ & 12 & 27 & 729 & 743 & 463 \\
\hline $10 / 01 / 2008$ & 34 & 114 & 1597 & 1463 & 422 \\
\hline $17 / 01 / 2008$ & 41 & 149 & 1780 & 1631 & 414 \\
\hline $31 / 01 / 2008$ & 55 & 244 & 2060 & 1888 & 517 \\
\hline $14 / 02 / 2008$ & 69 & 308 & 2680 & 2456 & 527 \\
\hline $28 / 02 / 2008$ & 84 & 364 & 2740 & 2511 & no sample \\
\hline $13 / 03 / 2008$ & 97 & 436 & 3520 & 3226 & 560 \\
\hline $27 / 03 / 2008$ & 111 & 498 & 4390 & 4023 & 587 \\
\hline $10 / 04 / 2008$ & 125 & 588 & 5400 & 4949 & 626 \\
\hline $24 / 04 / 2008$ & 139 & 683 & 5860 & 5370 & 625 \\
\hline 08/05/2008 & 153 & 850 & 6610 & 6057 & 617 \\
\hline $22 / 05 / 2008$ & 167 & 1035 & 9130 & 8367 & 442 \\
\hline 05/06/2008 & 181 & 1225 & 11610 & 10639 & 423 \\
\hline $19 / 06 / 2008$ & 195 & 1416 & 13810 & 12656 & 350 \\
\hline $17 / 07 / 2008$ & 223 & 1815 & 18640 & 17082 & 415 \\
\hline $14 / 08 / 2008$ & 251 & 2266 & 22100 & 20253 & 430 \\
\hline $11 / 09 / 2008$ & 279 & 2673 & no sample & no sample & 439 \\
\hline 09/10/2008 & 307 & 2992 & 28800 & 26392 & 419 \\
\hline $06 / 11 / 2008$ & 335 & 3225 & 30000 & 27492 & 401 \\
\hline $04 / 12 / 2008$ & 363 & 3368 & 29600 & 27126 & no sample \\
\hline 29/01/2009 & 419 & 3497 & 30800 & 27456 & no sample \\
\hline 26/02/2009 & 447 & 3566 & 29800 & 26565 & 428 \\
\hline $26 / 03 / 2009$ & 475 & 3740 & 29700 & 26475 & 452 \\
\hline 23/04/2009 & 503 & 3987 & 30200 & 26921 & 479 \\
\hline $21 / 05 / 2009$ & 531 & 4274 & 31500 & 28080 & 495 \\
\hline 18/06/2009 & 559 & 4659 & 30900 & 27545 & 424 \\
\hline 05/09/2009 & 638 & 5883 & 31400 & 27991 & 413 \\
\hline 08/10/2009 & 671 & 6306 & 33400 & 29774 & no sample \\
\hline 03/12/2009 & 727 & 6777 & 24600 & 21929 & 354 \\
\hline $30 / 12 / 2009$ & 754 & 6827 & 22500 & 20057 & 346 \\
\hline $28 / 01 / 2010$ & 783 & 6837 & 18940 & 17033 & 364 \\
\hline $26 / 02 / 2010$ & 812 & 6868 & 13030 & 11718 & 375 \\
\hline $26 / 03 / 2010$ & 840 & 7000 & 10460 & 9407 & 386 \\
\hline $27 / 04 / 2010$ & 872 & 7251 & 10480 & 9425 & 396 \\
\hline $27 / 05 / 2010$ & 902 & 7582 & 9400 & 8454 & 369 \\
\hline $25 / 06 / 2010$ & 931 & 7985 & 9350 & 8409 & 335 \\
\hline
\end{tabular}




$\begin{array}{lccccc}30 / 07 / 2010 & 966 & 8552 & 10200 & 9173 & \text { no sample } \\ 01 / 10 / 2010 & 1029 & 9421 & \text { no sample } & \text { no sample } & 376 \\ 29 / 10 / 2010 & 1057 & 9678 & 6210 & 5585 & 367 \\ 10 / 12 / 2010 & 1099 & 9794 & 6670 & 5999 & 357 \\ 04 / 01 / 2011 & 1124 & 9786 & 5610 & 4569 & \text { no sample } \\ 11 / 02 / 2011 & 1162 & 9940 & 3540 & 2883 & 335 \\ 11 / 03 / 2011 & 1190 & 10053 & 2370 & 1930 & 342 \\ 18 / 04 / 2011 & 1228 & 10391 & 2300 & 1873 & 350 \\ 23 / 05 / 2011 & 1263 & 10818 & 3110 & 2533 & 326 \\ 22 / 06 / 2011 & 1293 & 11202 & \text { no sample } & \text { no sample } & 304 \\ 03 / 01 / 2012 & 1487 & 13439 & 1375 & 1178 & \text { no sample } \\ 20 / 02 / 2012 & 1536 & 13584 & 855 & 733 & 330 \\ 12 / 03 / 2012 & 1557 & 13727 & 646 & 553 & 357 \\ 16 / 04 / 2012 & 1592 & 13985 & 716 & 613 & \text { no sample } \\ 15 / 05 / 2012 & 1621 & 14214 & 499 & 428 & 394 \\ 03 / 07 / 2012 & 1670 & 14872 & 415 & 356 & 395 \\ 03 / 08 / 2012 & 1701 & 15331 & 369 & 316 & 385 \\ 05 / 09 / 2012 & 1734 & 15853 & \text { no sample } & \text { no sample } & 394 \\ 04 / 10 / 2012 & 1763 & 16198 & 392 & 336 & 391 \\ 09 / 11 / 2012 & 1799 & 16454 & 413 & 354 & 402 \\ 07 / 12 / 2012 & 1827 & 16584 & 363 & 311 & 410 \\ 07 / 01 / 2013 & 1858 & 16722 & 335 & 260 & 372 \\ 18 / 02 / 2013 & 1900 & 16781 & 344 & 267 & 323 \\ 13 / 03 / 2013 & 1923 & 16823 & 350 & 272 & 278 \\ 18 / 04 / 2013 & 1959 & 16954 & 394 & 306 & \text { no sample } \\ 04 / 06 / 2013 & 2006 & 17423 & 402 & 313 & 300 \\ 30 / 11 / 2013 & 2185 & 19702 & 415 & 323 & 396\end{array}$

TABLE 1. Summary of measured conductivity values and local temperature data from Keele study site over the monitoring period. Conductivity and temperature data are from our new data and previously published data $(\underline{27}, \underline{50})$. No sample $=$ no fluid was able to be extracted. Stated measurements are averages with a $\pm 0.1 \mathrm{mS} / \mathrm{cm}$ accuracy. 


\begin{tabular}{|c|c|c|c|c|c|}
\hline Date & $\begin{array}{c}\text { Post- } \\
\text { burial } \\
\text { days / } \\
\text { interval } \\
\text { (PBI) }\end{array}$ & $\begin{array}{c}\text { Accum- } \\
\text { ulated } \\
\text { Degree } \\
\text { Days } \\
\text { (ADD) }\end{array}$ & $\begin{array}{c}\text { Field- } \\
\text { measured } \\
\text { 'grave' } \\
\text { conductivity } \\
(\mathrm{mS} / \mathrm{cm})\end{array}$ & $\begin{array}{c}\text { Rainfall } \\
\text { england- } \\
\text { corrected } \\
\text { grave } \\
\text { conductivity }\end{array}$ & $\begin{array}{c}\text { Field- } \\
\text { measured } \\
\text { 'control' } \\
\text { conductivity } \\
(\mathrm{mS} / \mathrm{cm})\end{array}$ \\
\hline $12 / 10 / 2010$ & 0 & 0 & - & - & - \\
\hline $28 / 10 / 2010$ & 16 & 132 & 570 & 1096 & 250 \\
\hline $04 / 11 / 2010$ & 23 & 206 & 780 & 1500 & 230 \\
\hline $11 / 11 / 2010$ & 30 & 248 & 500 & 961 & 190 \\
\hline $04 / 02 / 2011$ & 115 & 421 & 2300 & 4877 & 100 \\
\hline $04 / 03 / 2011$ & 143 & 572 & 3500 & 7421 & 100 \\
\hline $11 / 04 / 2011$ & 181 & 866 & 6900 & 14630 & 460 \\
\hline $11 / 05 / 2011$ & 211 & 1220 & 4500 & 9541 & 400 \\
\hline $14 / 06 / 2011$ & 245 & 1605 & 4600 & 9753 & 370 \\
\hline 07/07/2011 & 268 & 1936 & 5200 & 11026 & 310 \\
\hline $26 / 07 / 2011$ & 287 & 2204 & 6450 & 13676 & 250 \\
\hline $21 / 09 / 2011$ & 344 & 3008 & 17300 & 36682 & 850 \\
\hline $27 / 10 / 2011$ & 380 & 3449 & 16500 & no sample & 270 \\
\hline $12 / 01 / 2012$ & 457 & 4007 & 13220 & 22540 & 200 \\
\hline $06 / 03 / 2012$ & 511 & 4217 & 14000 & 23870 & 650 \\
\hline
\end{tabular}

TABLE 2. Summary of measured conductivity values and local temperature data from the UCLan study site over the monitoring period. Stated measurements are averages with a $\pm 0.1 \mathrm{mS} / \mathrm{cm}$ accuracy. 
Date

\begin{tabular}{|c|c|c|}
\hline $\begin{array}{l}\text { Post- } \\
\text { burial } \\
\text { days / }\end{array}$ & $\begin{array}{c}\text { Accum- } \\
\text { ulated } \\
\text { Degree }\end{array}$ & $\begin{array}{c}\text { Field- } \\
\text { measured } \\
\text { 'grave' }\end{array}$ \\
\hline $\begin{array}{c}\text { interval } \\
\text { (PBI) }\end{array}$ & $\begin{array}{c}\text { Days } \\
\text { (ADD) }\end{array}$ & $\begin{array}{c}\text { conductivity } \\
(\mathrm{mS} / \mathrm{cm})\end{array}$ \\
\hline
\end{tabular}

$\begin{array}{cc}\text { Rainfall } & \text { Field- } \\ \text { england- } & \text { measured } \\ \text { corrected } & \text { 'control' } \\ \text { grave } & \text { conductivity } \\ \text { conductivity } & (\mathbf{m S} / \mathrm{cm})\end{array}$

\section{8/08/11} 0

$09 / 09 / 11 \quad 22$

$15 / 09 / 11 \quad 28$

$19 / 09 / 11 \quad 32$

26/09/11 39

$29 / 09 / 11 \quad 42$

05/10/11 48

0

347

434

488

589

642

749

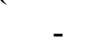

$12 / 10 / 11 \quad 55$

849

1918

4945

5475

4638

4103

8113

7600

8230

9660

24625

21805

9223

9647

10987

$28 / 10 / 11$

$13 / 12 / 11 \quad 117$

22/02/12 188

$24 / 04 / 12 \quad 250$

$04 / 05 / 12 \quad 260$

2343

$08 / 05 / 12 \quad 264$

2379

TABLE 3. Summary of measured conductivity values and local temperature data from the Cranfield study sites over the monitoring period. Stated measurements are averages with a $\pm 0.1 \mathrm{mS} / \mathrm{cm}$ accuracy. 
5

6

7

8

9

10

11

12

13

14

15

16

17

$\begin{array}{ccccc}\text { Year } & \text { England } & \text { Keele } & \text { UCLAN } & \text { Cranfield } \\ 2007 & 77.9 & 79.4 & - & - \\ 2008 & 81.8 & 75 & - & - \\ 2009 & 72.9 & 65 & - & - \\ 2010 & 60.6 & 54.5 & 116.5 & - \\ 2011 & 59.4 & 48.4 & 126 & 51 \\ 2012 & 93.8 & 80.4 & 160 & 80 \\ 2013 & 81.3 & 63.2 & - & - \\ \text { average } & \mathbf{7 5 . 4} & \mathbf{6 6 . 6} & \mathbf{1 3 4 . 2} & \mathbf{6 6}\end{array}$

TABLE 4. Summary of monthly average rainfall data from the respective study sites over the monitoring period. Measurements have $1 \mathrm{~mm}$ accuracy. 